\title{
A Comprehensive Review of Urban Regeneration Governance for Developing Appropriate Governance Arrangements
}

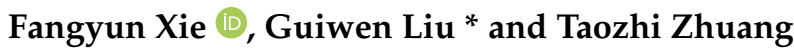 \\ School of Management Science and Real Estate, Chongqing University, Chongqing 400044, China; \\ xiefangyun@cqu.edu.cn (F.X.); tz.zhuang@cqu.edu.cn (T.Z.) \\ * Correspondence: gwliu@cqu.edu.cn; Tel.: +86-023-65120976
}

Citation: Xie, F.; Liu, G.; Zhuang, T. A Comprehensive Review of Urban Regeneration Governance for Developing Appropriate Governance Arrangements. Land 2021, 10, 545. https://doi.org/10.3390/land10050545

Academic Editor: Fabrizio Battisti

Received: 28 April 2021

Accepted: 18 May 2021

Published: 20 May 2021

Publisher's Note: MDPI stays neutral with regard to jurisdictional claims in published maps and institutional affiliations.

Copyright: (c) 2021 by the authors. Licensee MDPI, Basel, Switzerland. This article is an open access article distributed under the terms and conditions of the Creative Commons Attribution (CC BY) license (https:/ / creativecommons.org/licenses/by/ $4.0 /)$.

\begin{abstract}
Urban regeneration governance (URG) has become a popular issue in academia, politics and civil society because it has a significant influence on the success of urban regeneration activities. However, a comprehensive review on URG has yet to be produced, which hinders providing references to developing appropriate governance arrangements. Therefore, this study selected 88 relevant literatures from 1990 to 2019 to conduct a critical review. The goal of this review is to conceptualize URG, refine the signature elements of URG, compare the main modes of URG, and analyze the influential factors of URG. As a decision-making mode or a partnership, URG consists of three elements - partner, power and procedure-and influenced by three factors, the plan, place and person. There are three main modes of URG and each has pros and cons. Based on a comprehensive review, this paper concludes some findings and draws an $8 \mathrm{p}$ model that can provide an analysis framework for decision makers. Finally, four avenues for future research are proposed.
\end{abstract}

Keywords: conceptualization; signature elements; comparative study; influential factors; literature review; urban regeneration governance; urban development; $8 \mathrm{p}$ model

\section{Introduction}

Biesides urban sprawl, urban regeneration is a new strategy of urban development 1 [1]. It can effectively improve the urban physical environment [2], promote economic growth [3,4] and protect cultural heritage [3]. In general, urban regeneration projects include land reutilization [5], reconstruction of old residential buildings [6], redevelopment of brownfields [7], commercial area renewal [8] and other social and cultural improvements. According to different goals of the projects, the managers adopt diverse renewal measures, such as demolishing and rebuilding, repair and environmental restoration [5,9]. Different countries have their own understanding of urban regeneration due to their special history and nation context [1]. For example, urban regeneration referred to slum clearance after World War II, whereas it now refers to the improvement of urban competitiveness against the background of globalization. Nowadays, more and more cities are adopting urban regeneration to activate the old urban area and cope with the negative impacts of urban sprawl, especially in developed countries and some developing countries with rapid urbanization. The concept of urban regeneration has also become a hot topic of research among academic and practical professionals worldwide [10].

In 2020, the COVID-19 pandemic exerted an enormous influence on the global social, economic and environmental order. Our cities faced huge challenges when coping with the public health emergency, which enlightened people to rethink urban development related to complex issues such as public health [11]. Lack of health facilities and public space [12], uneven distribution of resources, weak management of community [12,13] and transnational movement of people [14] were highlighted as the core issues of urban governance and planning of the post-COVID-19 era. For global cities, the pandemic is a challenge as well as a once-in-a-lifetime chance. The new urban governance ecosystems and the new relationship among governments, corporations and civics are shaped [15]. 
Some new concepts of superblocks, tactical urbanism and 15-minute cities are proposed to optimize the urban design [16]. Natalie Mueller et al. proved that the superblock urban model could help cities become healthier [17]. Urban regeneration is an important approach to achieve these concepts of urban governance and design in the old urban area.

Despite the huge potential of urban regeneration, associated institutional, financial, organizational and managerial challenges have made it hard for cities to achieve expected goals and results $[18,19]$. Many academic and practical professionals have proposed that a lot of the challenges of urban regeneration come from inappropriate governance arrangements [20,21]. An appropriate governance arrangement can help distribute resources and power, organize partners and resolve conflicts of interest to achieve goals [22]. More and more attention has been paid to the institution, governance structure, participation, empowerment and other aspects of urban regeneration. Some studies have found a link between the performance of urban regeneration and the arrangement of governance. For example, if a region wants to activate the housing market and achieve positive economic growth, private enterprises are supposed to be involved in the governance process [23]. Likewise, if the planning of urban regeneration is failing to connect to the real world, it needs to encourage community participation [24]. However, there is still a continuous and open debate regarding what URG (urban regeneration governance) is and how to develop appropriate governance arrangements for urban regeneration. Meanwhile, the emergency of the COVID-19 pandemic also alerts people that the complexity of URG is increasing and changing constantly. Thus, it is valuable to conduct an integrated review of URG to provide a comprehensive understanding of URG, a reference and a guideline for decision makers and to identify the definition, elements, categories and influential factors (as analyzed in this paper) of URG.

Building on previous studies, this paper conducted a comprehensive review of URG. At first, we conceptualized URG. Although many previous articles have explored the definition of URG, a consensus agreement is still lacking. In the research methodology section, we explain the research process and framework and the overview of selected papers. We discuss the selected papers in three aspects: the signature elements of URG, the different modes of URG and the factors influencing URG. As for the first aspect, we refine the elements from selected papers to form a general formula of URG. The second aspect compares the different governance modes by describing the signature elements and pros and cons. The third aspect aims to seize the influential factors of URG. Although the research themes of selected papers are diverse, these papers happened to coincide with each other on the key factors of URG. In the discussion and conclusion section, we proposed some findings and tried to give some suggestions for future research.

\section{Conceptualizing the URG}

Schenkel stated that URG must address each dimension of urban regeneration, analyze the role, power, and gain and loss of each stakeholder and find the barriers and obstacles of the renewed process [25]. There is still not a standard definition of URG in scholarly articles or publications of professionals. Hence, we collated the definitions of "urban regeneration", "governance" and "urban governance" to define URG (see Appendices A-C).

Urban regeneration. Urban regeneration can also be called "urban renewal", "urban redevelopment", "urban rehabilitation" or other lesser-used concepts. There a slight difference among these concepts. The 1949 US Housing Act pointed out that "urban renewal project can be all-redevelopment, or all-rehabilitation, or a combination of the two" [9]. Urban regeneration is meant to cope with urban decay while urban renewal fosters new development of cities [26]. Compared with other countries, European countries implemented urban regeneration projects first and gained ground rapidly [27]. In earlier times, urban regeneration was just regarded as a strategy to transform the physical and economic conditions of slums and evict the poorer segments [28,29]. Then, in the 1970s, most urban regeneration projects were led by capitalists and used to profit from property development, which did not guarantee public interests and caused gentrification [26]. 
Because housing prices and rents increased, people with low incomes were replaced by higher-income social classes [30]. Nowadays, urban regeneration can be seen as a process of realizing a comprehensive vision and sustainable development [31,32]. The contents of urban regeneration included providing affordable housing for low-income groups, providing parks and walkways, retrofitting infrastructure, increasing job opportunities, repairing the urban fabric, promoting social inclusion and so on [33,34]. A complex decision-making process is inevitable in urban regeneration because of a wide variety of actors [23]. The collaboration between stakeholders with different qualities, motivations and resources is the key feature of urban regeneration [35]. Pollock and Sharp pointed out that urban regeneration requires continuous experiences and the establishment of trust due to its long duration and high costs [24].

Governance. For a long time, governance is a pattern of rule or ruling activities in English [36]. Neo-institutionalists spread the word of "governance" from 1970 to depict enterprises' internal management and administration [22]. Later, the term of governance was introduced to the field of public administration. In a broad sense, it represents emerging decision-making modes that differ from the hierarchical power of government and towards making full use of the market and networks [36]. Tasan-Kok defined governance as a process by which various actors, groups and institutions achieve a common goal and coordinate decision-making [37]. Atkinson and Boisseuil proposed that governance means the changes of institutional arrangement, the understanding of principles and modes of various actors and power over the implementation of each domain [38,39]. Nicholas J. Price pointed out that governance includes structure, oversight responsibilities, talent and culture and infrastructure [40]. However, it is difficult to define the beginnings and endings of governance [41], and sometimes, governance also will be a failure. Thus, good governance was proposed to deal with the governance failure. Good governance refers to not only the effective implementation of policies but also the availability of civil rights [42]. The United Nations Development Program defined good governance as participatory, transparent and accountable. The Institute on Governance also proposed five key elements of good governance, namely direction, accountability, legitimacy and voice, fairness and performance [43].

Urban governance. In a narrow sense, urban governance can be regarded as an approach dealing with various urban affairs, including providing services to citizens, attracting investment and creating jobs [44]. In a broad sense, it refers to blending the differences of stakeholders [21], making the decision-making process more cooperative, democratic, transparent and inclusive [45], and achieving financial decentralization, political decentralization and empowering civic and social groups [46]. Hemphill et al., argued that urban governance includes corporate thinking, political systems, public management and strategic planning [47]. Urban governance does not have an ideal model. Gopakumar held that urban governance is both a technical exercise and a managerial exercise [48]. From the perspective of regime theory, urban governance has a strong link with the urban regime. The politicization of urban space [49] influences the urban regeneration arrangement. Pierre pointed out that urban governance arrangement is not value-neutral and always represents the political value of some parties [50]. Sometimes, urban governance reflects the consistent control of the central government over the local government [51]. In order to consolidate leadership and political philosophy, the ruling party would propose or advocate new urban governance arrangements, such as urban regeneration activities, and apply them in urban affairs. In other words, the governance structure, policies, institutional arrangement and decision-making measures of urban regeneration activities are the microcosm of the urban regime.

Berkel divided the integrated urban development model into two dimensions: substantive and procedural [52]. The substantive dimension is related to the actions and the procedural dimension is related to the managerial ways, institutions and partnerships. Obviously, URG belongs to the procedural dimension of urban regeneration activities and an intersection of urban regeneration and urban governance (Figure 1). By combining 
these definitions and refining some keywords, such as "decision-making", "various actors", "power", "institutional arrangement", we can give the following definition of URG: URG is the decision-making mode, the partnership and the institutional arrangement for dealing with events of urban regeneration; URG specifies the rights and accountabilities of different actors when making a decision; URG formalizes policies, standards and procedures for guiding the decision-making.

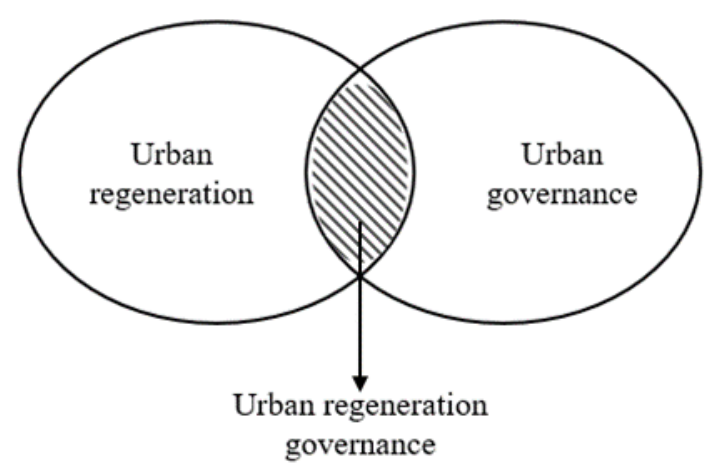

Figure 1. The definition of urban regeneration governance.

\section{Methodology}

\subsection{Paper Retrieval}

The comprehensive literature review always starts with collecting, selecting and screening related publications. We identified several keywords derived from the definition of urban regeneration and some similar concepts, namely urban, community, neighborhood, renewal, regeneration and governance. The search rules Title $(\mathrm{TI})=($ urban OR community OR neighborhood) AND Title $(\mathrm{TI})=$ (renewal OR regeneration) AND Topic $(T S)=$ (governance) were used as the Topic Search criterion in the Web of Science Core Collection database. The search was conducted for the period between 1990 and 2019, and 272 papers were identified for further screening. The flow of the screening process is shown in Figure 2.

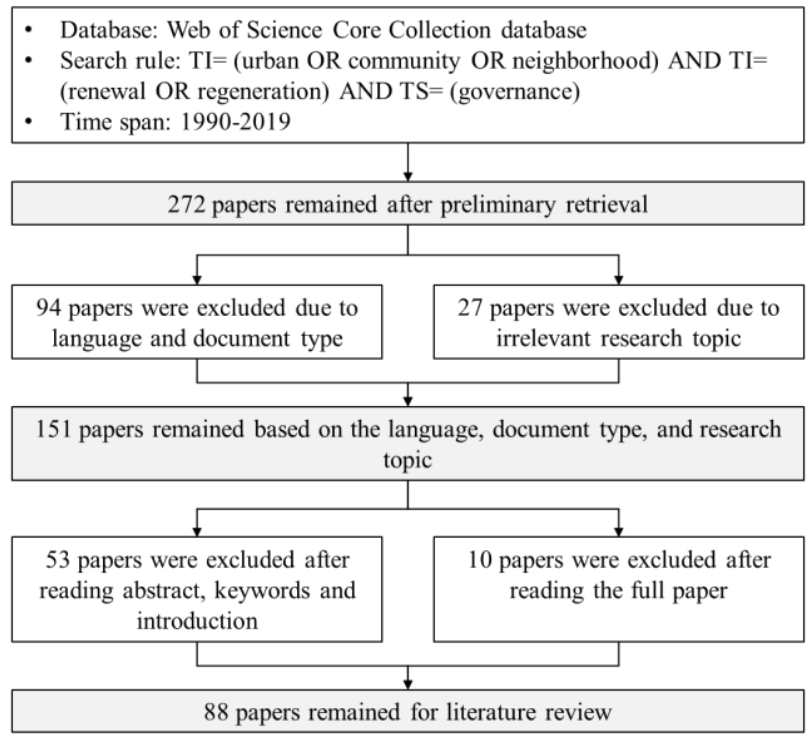

Figure 2. The flow of the screening process.

Based on the language, document type, and research topic, we implemented the first screening. A total of 94 papers were excluded due to language and document type. We collected papers using the English language. Meanwhile, meeting papers, reviews, abstract, 
news and editorials were rejected to ensure the quality of papers. Then, according to the research topic and focus, 151 articles remained to implement in the next screening.

The second screening was divided into extensive reading and intensive reading. The extensive reading stage included the abstract, keywords and introduction. Although some articles dealt with urban regeneration and mentioned urban regeneration governance, the focus of those articles may not be relevant to our review. Therefore, 53 papers were excluded. The intensive reading stage required an in-depth read of the full paper. If the articles cannot provide valuable opinions and results of urban regeneration governance, they are removed. Finally, 88 papers were selected for analysis.

\subsection{A Brief Quantitative Overview of Selected Papers}

A brief quantitative overview of the selected papers was devised. Table 1 lists the journals from where we retrieved the selected papers. Urban Studies is the biggest sources of selected articles. Europe-Asia Studies, International Journal of Urban and Regional Studies and Journal of Housing and the Built Environment also provide many papers. The publication sources demonstrate that the selected papers were mostly relevant to urban and regional development.

Table 1. The journals and the number of corresponding publications.

\begin{tabular}{|c|c|}
\hline Journal Title & Number \\
\hline Urban Studies & 15 \\
\hline International Journal of Urban and Regional Studies & 8 \\
\hline Europe-Asia Studies & 8 \\
\hline Journal of Housing and the Built Environment & 7 \\
\hline Policy and Politics & 4 \\
\hline Local Government Studies & 4 \\
\hline Cities & 4 \\
\hline Tijdschrift voor Economische en Sociale Geografie & 2 \\
\hline Sustainability & 2 \\
\hline Regional Studies & 2 \\
\hline Public Administration & 2 \\
\hline Policy Studies & 2 \\
\hline Housing Studies & 2 \\
\hline Habitat International & 2 \\
\hline European Planning Studies & 2 \\
\hline Voluntas & 1 \\
\hline Urban Research E Practice & 1 \\
\hline Urban Geography & 1 \\
\hline Urban Affairs Review & 1 \\
\hline Sustainable Development & 1 \\
\hline Sociology-The Journal of The British Sociological Association & 1 \\
\hline Research in Transportation Economics & 1 \\
\hline Regional Studies, Regional Science & 1 \\
\hline Public Money E Management & 1 \\
\hline Public Management Review & 1 \\
\hline Public Administration Review & 1 \\
\hline Progress in Planning & 1 \\
\hline Land Use Policy & 1 \\
\hline Journal of Regional and City Planning & 1 \\
\hline International Journal of Urban Sciences & 1 \\
\hline Environment and Planning D: Society and Space & 1 \\
\hline Environment and Planning $A$ & 1 \\
\hline Canadian Journal of Development Studies & 1 \\
\hline Boletinde la Asociacion de Geografos Espanoles & 1 \\
\hline Australian Geographer & 1 \\
\hline Asia Europe Journal & 1 \\
\hline Area & 1 \\
\hline Total & 88 \\
\hline
\end{tabular}


As shown in Figure 3, although the number of papers between 2013 and 2015 reduced, there is a growing trend in the number of papers published from 1990 to 2019. The trend indicates a sustainable research interest in this topic. Between 2009 and 2012, scholars paid the most attention to urban regeneration governance. The earliest paper was published in 1995 . About $75 \%$ of selected articles were published in the past 10 years, which also indicates that the attention on urban regeneration governance is increased in recent years and the result are relatively new. The research methods are fairly consistent, $82 \%$ of selected papers adopted empirical studies, $15 \%$ of selected papers adopted theoretical studies, and others adopted both methods. The empirical studies can provide more objective data for this paper. The regeneration cases in the selected papers were collected from different countries. The largest number of regeneration cases comes from the UK, which is unsurprising because the UK has a long history and rich experience of urban regeneration [53]. Many of the remaining cases come from the Netherlands, Spain, China and the US. The number of regeneration cases in Europe is more than in other continents on account of rapid urbanization.

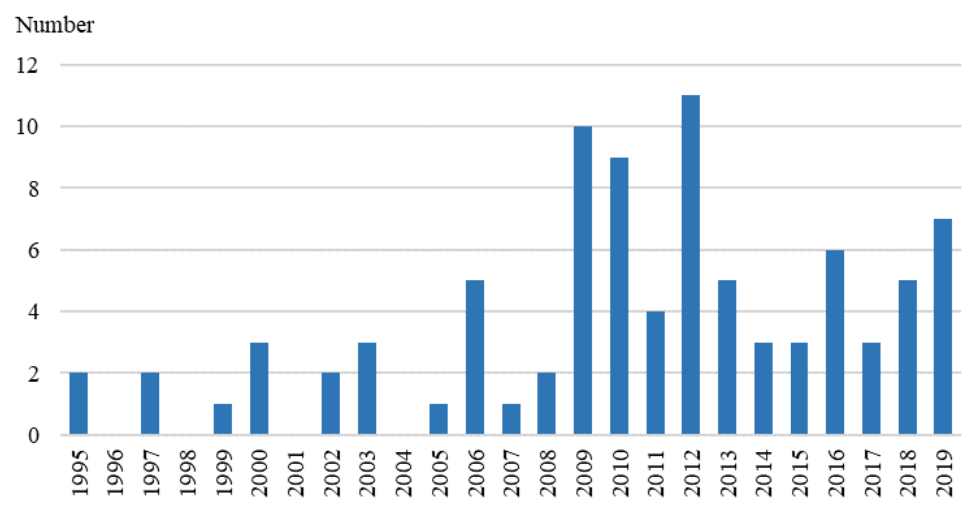

Figure 3. The publication year of selected papers.

\section{Review of Studies on URG}

This comprehensive review aims to identify, understand and analyze the URG to help decision makers develop a suitable URG mode. In this paper, the URG modes are arrangements of participants of urban regeneration activities and their power, tasks and benefits. For this purpose, there are three significant realms that need to be explored: (1) the signature elements which describe the general formula of URG mode, (2) the categories of URG modes based on different arrangements of signature elements, and (3) the factors influencing the practice of URG. By reading the selected papers, we concluded signature elements, categories of URG modes and the influential factors (see Appendix D). Partner, procedure and power were refined to describe the general formula of URG mode. We found that regardless of the category of the URG mode, URG is a process wherein one or more partners use their power to make decisions during some procedures, that is, "URG = partner + power + procedure". In light of the arrangements of partner, power and procedure, the URG modes can be divided into three categories, government governance, entrepreneurial governance and civic governance, which are from "top-down" to "bottomup". Each governance mode has pros and cons. According to cases of previous studies, different URG modes in a particular situation can generate different results, which proved that the success of URG is influenced by some factors. We collected these factors from the selected papers and divided them into three categories: plan, place and person. Thus, we developed a research framework (shown in Figure 4) to analyze URG. 


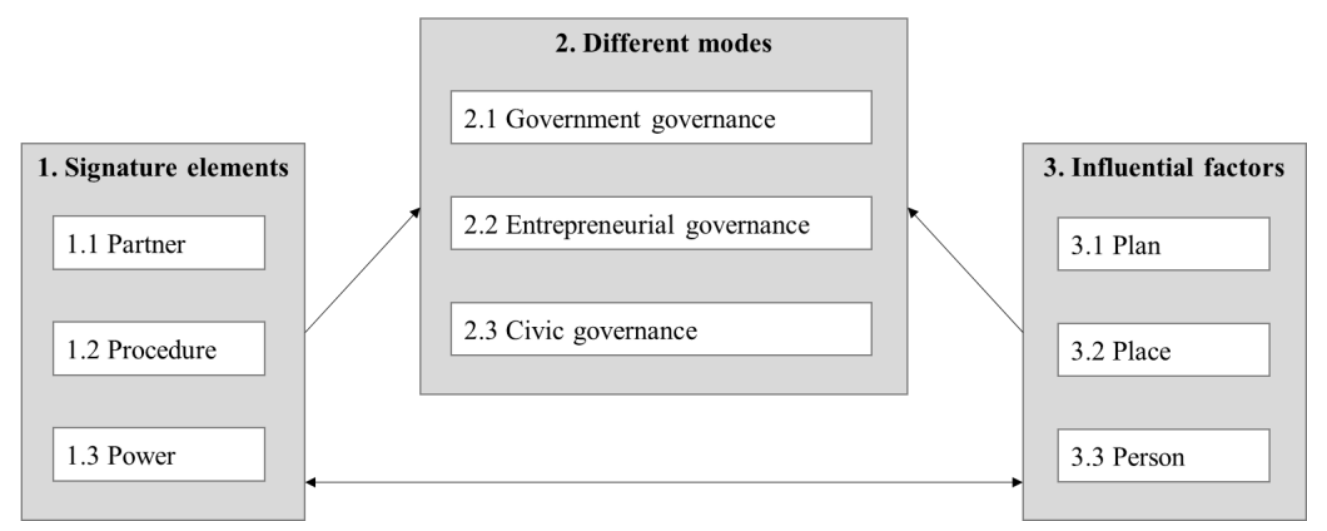

Figure 4. Research framework.

\subsection{The Signature Elements of the URG}

\subsubsection{Partner}

The range of partners of urban regeneration is very broad; they can come from the government, market and society $[54,55]$. Both in the past and now, governments have always held a place in URG owing to their credibility and authority [21]. Governments can be divided into central governments and local governments [29]. The central government drives most previous urban regeneration projects in order to plan and allocate resources well, such as the Council House Building Programme of the UK [56]. However, due to the different urban regimes, the local regeneration is not controlled by the central government. In most cases, local governments play a more predominant role in local regeneration than the central government due to the different urban regime [28]. Market partner means private sector. Amid globalization, regionalism, environmentalism and neo-liberalism, governments encourage private sectors to participate in urban regeneration to promote market-driven economic revival of cities [38,57]. Private sectors always remain synonymous with capitals, productivity and efficiency in the events of urban regeneration [58]. Civil society groups are diverse, such as citizens, NGOs, volunteers, universities and media. In recent years, civil society engagement was repeatedly emphasized to protect the rights of civics [59]. However, it seems that voluntary and community sectors still play little or no role in procedures of URG [60]. Ball and Maginn proposed that not all partners will be involved in URG and the demarcation line of partners is sometimes blurred [56].

\subsubsection{Procedure}

Urban regeneration includes four procedures: scoping, planning, financing and implementation [61]. URG is related to all procedures and the procedure arrangement of partners has a significant influence on the final results of urban regeneration [62]. For example, Newman found that public sectors control the bidding process is very important because the bidding process needs to take public-good goals into consideration [63]. In addition, Lawson and Kearns concluded that it is necessary to keep community groups engaged throughout planning and implementation to ensure sustainable benefits [64]. Unclear procedure arrangements of partners have a negative effect on results of urban regeneration. For example, it is important to learn from the experience of neighborhood regeneration in Pairs, which had a blurry procedure arrangement as several departments were involved in the same activities, which made things harder [39]. In URG, procedure is a highly complicated issue in which actors participate.

\subsubsection{Power}

Power is depicted as the capability to influence the process of events, to change behaviors and attitudes, and get people to do something they would not otherwise do [47,65]. Power politics emerge and evolve when partners participate in URG and influence the governance structure [55]. Generally, the distribution of power among the URG partners is hard to 
balance [58]. Community groups and voluntary sectors often cannot hold actual power, and the central government often retains a concentration of power [56,65]. Van Bortel illustrated that the imbalance of power could produce quite hierarchical relationships that focus on fewer actors [66], in which the views of the powerful agency override the others [65]. On the contrary, Ball and Maginn thought the balanced distribution of power might cause high costs and inaction, leading to dissatisfaction among each stakeholder [56]. Moreover, it is challenging to distribute the power of actors with diverse interests and expectations [66]. Ward posited that the circumstances and the partners of governance would determine the form of the power structure [67]. For example, there is evidence to suggest that the centralization of power in the central and local governments is good for URG with the private sector involved [68].

\subsection{The Different Modes of URG}

Recent urban regeneration emerged from seeking to reconstruct European cities at the end of World War II [32]. Since then, urban regeneration has experienced four periods: post-war reconstruction, renewal for providing public welfare, redevelopment owing to globalization and regeneration for sustainable development $[21,56,69]$. Different URG modes emerged in light of the different features of each period [31,70]. These modes reflected the transformation of URG from top-down to bottom-up and from unitary to multiple [24]. According to the partner, power and procedure, the URG can be split into three main modes: government governance, entrepreneurial governance and civic governance (see Figure 5, Table 2).

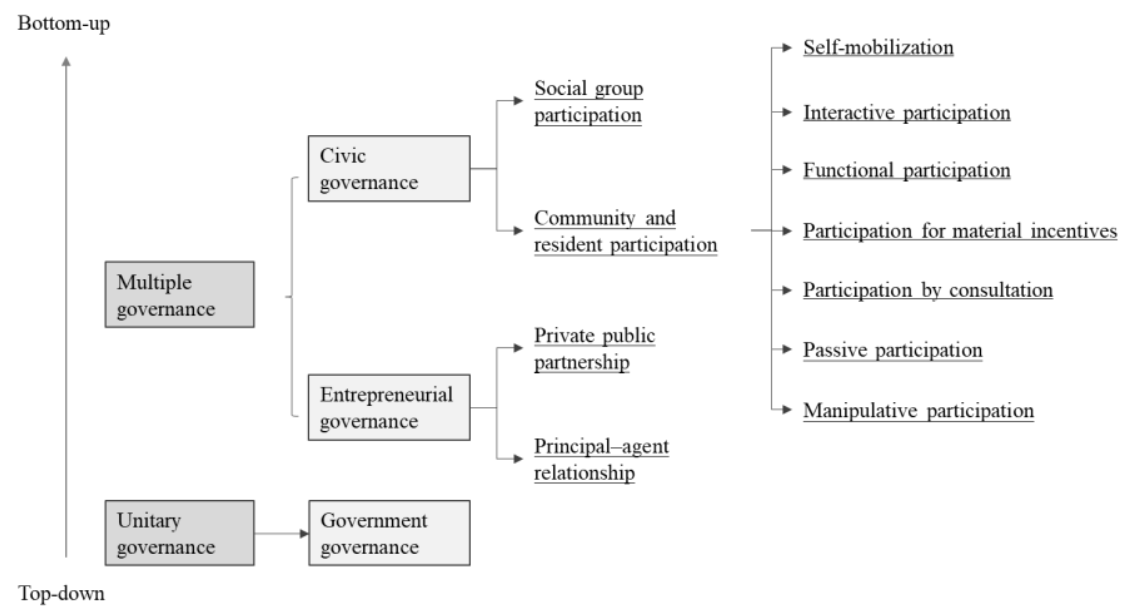

Figure 5. The categories of URG modes. 
Table 2. The signature elements (partner, procedure, power) and pros and cons of different modes of URG.

\begin{tabular}{|c|c|c|c|c|c|}
\hline Mode & Partner & Procedure & Power & Pros & Cons \\
\hline \multirow{5}{*}{$\begin{array}{l}\text { Government governance } \\
\text { (Period: post-war } \\
\text { reconstruction and renewal } \\
\text { for providing public welfare) }\end{array}$} & \multirow{4}{*}{ Governments } & Scoping & $\begin{array}{l}\text { Defining a vision for the city or region } \\
\text { Identifying key actions }\end{array}$ & \multirow{5}{*}{$\begin{array}{c}\text { Can effectively allocate many } \\
\text { resources } \\
\text { Can avoid a lot of process } \\
\text { examinations } \\
\text { Can pay more attention to } \\
\text { deprive districts } \\
\text { Can take social goals into } \\
\text { consideration }\end{array}$} & \multirow{5}{*}{$\begin{array}{c}\text { Causing cost overage and failure of the } \\
\text { budget } \\
\text { Creating financial pressure } \\
\text { Achieving an elitist vision and } \\
\text { rejection by the citizens } \\
\text { Bureaucracy and corruption } \\
\text { Causing the absence of transparency } \\
\text { and accountability } \\
\text { Racial segregation }\end{array}$} \\
\hline & & Planning & $\begin{array}{c}\text { Making a planning framework and a master plan } \\
\text { Defining design standards }\end{array}$ & & \\
\hline & & Financing & $\begin{array}{c}\text { Making capital plans and a regulatory framework } \\
\text { Providing funds }\end{array}$ & & \\
\hline & & Implementation & $\begin{array}{c}\text { Managing projects } \\
\text { Supervising and examining the delivery }\end{array}$ & & \\
\hline & Enterprises & Implementation & $\begin{array}{l}\text { Delivering projects according to the instruction of } \\
\text { governments }\end{array}$ & & \\
\hline \multirow{6}{*}{$\begin{array}{l}\text { Entrepreneurial governance } \\
\text { (Period: redevelopment } \\
\text { owing to globalization) }\end{array}$} & & Scoping & $\begin{array}{l}\text { Defining a vision for the city or region } \\
\text { Identifying key actions }\end{array}$ & \multirow{6}{*}{$\begin{array}{l}\text { Much more effective at } \\
\text { raising money and using the } \\
\text { money } \\
\text { Relieving financial } \\
\text { pressurePromoting economic } \\
\text { growth quickly } \\
\text { Sharing the development } \\
\text { costs and risks } \\
\text { Improving the resource use } \\
\text { efficiency } \\
\text { Producing better and more } \\
\text { efficient policy outcomes }\end{array}$} & \multirow{6}{*}{$\begin{array}{c}\text { Causing market values override } \\
\text { broader civic values } \\
\text { Reducing the actions for promoting } \\
\text { social inclusion and equity } \\
\text { Cannot promote the shift about } \\
\text { changing democracy, legitimacy, and } \\
\text { the depoliticization } \\
\text { Lacking transparency and democratic } \\
\text { control } \\
\text { Corruption } \\
\text { Hard to supervise the behaviors of } \\
\text { private sectors } \\
\text { Gentrification and social exclusion } \\
\text { Rising living costs and unemployment } \\
\text { Damaging the cultural heritage and } \\
\text { deteriorating the old neighborhoods }\end{array}$} \\
\hline & & Planning & $\begin{array}{l}\text { Organizing the design of planning framework } \\
\text { and master planning and make decisions } \\
\text { Partnering arrangements with the private sector }\end{array}$ & & \\
\hline & & Implementation & $\begin{array}{l}\text { Laying out necessary institutional arrangements } \\
\text { and contracts } \\
\text { Supervising the projects implementation and } \\
\text { behavior of private sectors }\end{array}$ & & \\
\hline & \multirow[t]{2}{*}{ Enterprises } & $\begin{array}{l}\text { Planning } \\
\text { Financing }\end{array}$ & $\begin{array}{l}\text { Participating in the design of planning framework } \\
\text { and master planning and asking for things } \\
\text { Raising funds and making capital plans }\end{array}$ & & \\
\hline & & Implementation & $\begin{array}{c}\text { Managing projects, delivering projects and even } \\
\text { operating projects }\end{array}$ & & \\
\hline & Residents & Implementation & Asking for compensation & & \\
\hline
\end{tabular}


Table 2. Cont.

\begin{tabular}{|c|c|c|c|c|c|}
\hline Mode & Partner & Procedure & Power & Pros & Cons \\
\hline \multirow{11}{*}{$\begin{array}{l}\text { Civic governance } \\
\text { (Period: regeneration for } \\
\text { sustainable development) }\end{array}$} & \multirow{4}{*}{ Governments } & Scoping & $\begin{array}{l}\text { Organizing meetings for generating a vision for } \\
\text { the city or region and making decisions with other } \\
\text { stakeholders } \\
\text { Identifying key actions with other stakeholders }\end{array}$ & \multirow{11}{*}{$\begin{array}{l}\text { Stimulating and harnessing } \\
\text { the energy of local people } \\
\text { and good for solving local } \\
\text { challenges } \\
\text { Bolstering the legitimacy of } \\
\text { urban regeneration projects } \\
\text { Enlivening the local } \\
\text { communities and place } \\
\text { identity } \\
\text { Attracting multiple } \\
\text { investments } \\
\text { Increasing social inclusion } \\
\text { and social cohesion } \\
\text { Good for protecting historical } \\
\text { heritage and culture } \\
\text { Relieving financial pressure } \\
\text { Sharing the development } \\
\text { costs and risks }\end{array}$} & \multirow{11}{*}{$\begin{array}{c}\text { Decision making is ineffectual } \\
\text { sometimes } \\
\text { An inevitable gap between } \\
\text { bureaucratic reality and participant } \\
\text { expectations } \\
\text { Accountability raised by partnerships } \\
\text { have proven difficult to address } \\
\text { Added to a sense of complex } \\
\text { governance } \\
\text { The realization of bottom-up } \\
\text { decision-making is often the result of } \\
\text { top-down governmental choice } \\
\text { Complex partners might result in } \\
\text { time-consuming debates and } \\
\text { stalemates } \\
\text { The marginalized groups are still } \\
\text { excluded from participation } \\
\text { Increasing the communication } \\
\text { costsCorruption }\end{array}$} \\
\hline & & Planning & $\begin{array}{c}\text { Organizing the design of planning framework } \\
\text { and master planning and make decisions with } \\
\text { other stakeholders }\end{array}$ & & \\
\hline & & Financing & Provide part funds or not & & \\
\hline & & Implementation & $\begin{array}{l}\text { Supervising the project implementation (legality, } \\
\text { safety, quality) }\end{array}$ & & \\
\hline & \multirow{3}{*}{ Enterprises } & Scoping & $\begin{array}{l}\text { Participating the meetings of generating a vision } \\
\text { and expressing views }\end{array}$ & & \\
\hline & & Planning & $\begin{array}{l}\text { Participating the design of planning framework } \\
\text { and master planning and asking for things }\end{array}$ & & \\
\hline & & Financing & Raising funds or not & & \\
\hline & \multirow{4}{*}{ Residents } & Scoping & $\begin{array}{l}\text { Participating or organizing meetings for } \\
\text { generating a vision } \\
\text { Identifying key actions of projects }\end{array}$ & & \\
\hline & & Planning & $\begin{array}{c}\text { Participating or organizing the design of planning } \\
\text { framework and master planning and } \\
\text { make decisions }\end{array}$ & & \\
\hline & & Financing & $\begin{array}{c}\text { Analyzing municipal finance tools } \\
\text { Raising funds, making capital plans and a } \\
\text { regulatory framework }\end{array}$ & & \\
\hline & & Implementation & $\begin{array}{l}\text { Supervising the project implementation (cost, } \\
\text { time, quality) and behavior of private sectors }\end{array}$ & & \\
\hline
\end{tabular}


Table 2. Cont

Helping to generate a vision

Helping to conduct a strategic assessment to

Scoping direct future development of the city and the
region, including economic, social and

Social groups physical features

Planning Helping to design a planning framework and

master planning

Implementation Helping to guide the project implementation 


\subsubsection{Government Governance}

In the period of post-war reconstruction and renewal for providing public welfare, urban regeneration was associated with rebuilding cities, resuming production and economic activity, clearing slums, providing social housing and eradicating poverty [69]. Governments were regarded as a steerer in delivering these programs, which was influenced by Keynesian welfare-state systems [71]. Thus, government governance also became the dominant mode to deal with events of urban regeneration (Table 2). Both the Council House Building Programme in the UK [56] and the 1949 federal Housing Act in the US [69] adopted the government governance mode.

In general, government governance involves two partners: governments and enterprises. Governments need to make all relevant decisions from the scoping phase to the implementation phase, and try to take everything under control [72]. Firstly, in the scoping phase, governments define a vision of the city by analyzing the position, economy, society, environment and resources of the city or region [61]. The vision is essential because it determines the future development of the city. Then, governments devise a planning framework and a master planning and develop some design standards for direct implementation [19]. In financing phases, governments underwrite almost all of the development costs. To make full use of resources, governments also need to develop capital plans and a regulatory framework [69]. Finally, governments will supervise the renewal process and examine the delivery to guarantee quality [61]. Compared with governments, under the mode of government governance, enterprises barely have opportunities to make some decisions and they can only deliver projects according to the instruction of governments [21].

Government governance had long been criticized by professionals and scholars. On the one hand, governments have to pay for everything of urban regeneration under the government governance mode, which causes huge financial pressure [39]. Furthermore, due to bureaucracy and corruption, the development costs are often overage and the budget is nearly always ineffective [73]. On the other hand, government governance achieves an elitist vision of cities and ignores the actual demands of other stakeholders [74]. For example, the urban regeneration projects of the 1949 American federal Housing Act were designed by white elites and damaged the interests of Black Americans [69]. Of course, government governance also has some pros. Sagan and Grabkowska proposed that government governance effectively promotes the physical regeneration of cities [70]. Additionally, more attention will be paid to the most deprived regions under government governance and more welfare polices to achieve social goals will be set [39].

\subsubsection{Entrepreneurial Governance}

The fact that the government cannot afford all public expenditures led to the collapse of the Fordist-Keynesian regime and the failure of government governance [57]. Meanwhile, globalization, regionalism, environmentalism and neo-liberalism caused uneven development among different cities, compelling cities to search for new governance mode to attract capital, drive economic growth and reduce administration costs [75-77]. Thus, entrepreneurial governance was launched and became popular in capitalist countries.

Entrepreneurial governance means that the government engages with the private sector and they form a public and private coalition to implement urban regeneration together $[32,57]$. Therefore, the partners of entrepreneurial governance are governments and private enterprises (Table 2). Under entrepreneurial governance, the government is regarded as a facilitator or a negotiating party and even plays a marginal role in urban regeneration [32,78]. Conversely, the private sector determines a lot of decisions in some aspects [79].

There are two main ways to achieve entrepreneurial governance: principal-agent relationships and public-private partnerships. The differences in these two ways are the distribution of power and procedures between public and private sectors. The Urban Renewal Authority (URA), as a semi-official corporate organization in Hong Kong, is an example of the principal-agent relationship [78]. Public sectors such as the URA sell land to 
private sectors and supervise the implementation of the private sector and get a cut of the profits instead of developing a region directly [38]. On the other hand, the private sectors need to finance and implement the projects [32]. In this way, public sectors still control the proposal and the strategical planning, while private sectors can only react to the formulated planning [23]. Unlike the principal-agent relationship, urban regeneration projects with a public-private partnership (PPP) have a special purpose company consisting of public sectors and private sectors and implement the projects directly, such as the European Urban Regeneration Companies [79,80]. In PPP, private sectors can be involved early in each process and generate the vision and develop strategic planning and proposals with public sectors [79]. However, no matter which way is applied, residents are regarded as "largely invisible" and can only ask for compensation during project implementation [19,78].

Entrepreneurial governance was proposed to deal with failed federal urban regeneration projects because it can help to handle the fiscal crisis, promote the local economy, improve output at lower costs and share the risks [23]. Though entrepreneurial governance can bring about positive consequences, it also has a lot of disadvantages. Bernt stated that entrepreneurial governance ignores many fields of urban development and pays more attention to the economic outcomes and housing market equilibrium [76]. The deprived areas are always rebuilt into commercial or high-end districts to gain more money, which compel the poor to leave their homes [68]. Obviously, the inhabitants are still excluded during the decision-making process and only elites are allowed to make decisions [77]. Therefore, the transparency, fairness and democracy of entrepreneurial governance is often called into question [23]. Vento concluded that corruption and social inequality ultimately prevail once control of private sectors is lost [77].

\subsubsection{Civic Governance}

The coalition of the state and the market is on the verge of collapse due to the global financial crisis and industrial restructuring in 1990, with more and more people focusing on the notions of good governance and democratic decision-making [81]. Thus, as an alternative to government governance and entrepreneurial governance, civic governance gains more attention $[13,82]$ (Table 2). Civic governance seeks to deal with regeneration failures and achieve desirable outcomes, such as social inclusion, democracy and sustainable development [83]. Glackin and Dionisio also pointed out that civic participation is fundamental to generate trust and dependability to implement urban policies, although it is challenging to accomplish this [34].

In a narrow sense, civic governance means that residents can be involved in each decision-making process and enjoy equal rights [65]. Glackin and Dionisio thought that residents are a valuable and vital source to collect information and ideas of local areas, especially in the vision and planning phases [34]. Broadly speaking, "civics" not only refer to the residents, but also include some social groups such as volunteers, universities, NGOs and media groups [84]. These groups often play the role of coordinator to coordinate and balance the relationship among the government, residents and markets with their special knowledge and skills [60]. In addition, some groups will donate money or resources to promote urban regeneration [19].

Governments and enterprises still play a key role in civic governance, whether in the vision and planning phases or the financing and implementation phases [85] (Table 2). Governments, as an organizer or a servant, need to arrange meetings to reach an agreement among stakeholders on various aspects of urban regeneration. Enterprises can also express their opinions and ask for things. At the same time, parts of regeneration funds coming from governments and enterprises [19]. Under ideal conditions, there should be a balanced power distribution among the civics, governments and enterprises. However, in practice, civics are always excluded from formal decision-making and play little or no role [29,82], and the key decisions are still negotiated among some powerful actors [86]. Savini complained that the accomplishment of bottom-up decision-making results from a top-down governmental decision [87]. 
Jones divided citizen participation into seven levels, from manipulative participation to self-mobilization [88]. In most citizen participation cases, only the first five ways and the last two ways are rarely implemented in practice. On the one hand, it is almost impossible to empower all citizens because the number of citizens is too large to manage [89]. On the other hand, the lack of resources, skills, capital and awareness limits citizen involvement [31,83], but this does not mean that self-mobilization cannot be achieved. Kleinhans [90] recorded a way of citizen participation called community enterprises, which are established by local citizens and independent from governments. Community enterprises are not-forprivate-profit groups and address the serious deficiencies of areas where other actors cannot provide solutions.

Civic governance is seen as an effective mode to achieve sustainable development [60]. Muir and Rhodes pointed out that the aims of promoting civic participation include, but are not limited to, ensuring the legitimation of projects, developing skills and networks of civics and providing local information to designers [65]. Meanwhile, citizen participation is good for civic political participation, local economic growth, sense of belonging and civic identity and esteem [34,72]. However, civic governance also has been criticized by some scholars. Foley and Dicks proposed that civic governance may exacerbate social exclusion rather than social inclusion due to fragmentation of local people and internal dissent and conflict [29,91]. Moreover, engaging citizens in urban regeneration would lead to going over budget, as well as delays, conflict and division [83], as it is very difficult for all people to come to an agreement, especially in deprived areas where there is a lack active civil society [87,91]. In addition, neighborhood managers feel colossal pressures from both above and below due to the overemphasis on civic governance [92].

\subsection{The Factors Influencing the Practice of URG}

\subsubsection{Plan}

The planning of cities can be divided into vision of city and region, and the targets of neighborhoods, communities or projects [32]. The city's vision depicts the future trajectory of the city and as a guide to establishing differential targets of urban regeneration projects $[48,66]$. In this case, it is unlikely to form a stable and single partnership among various actors [70]. Parés concluded that if decision makers choose a less comprehensive target of urban regeneration rather than a more comprehensive one, the plural participation can become dysfunctional for institutions rather than become a basic instrument [93]. Similarly, when economic and political interests dominate the targets of urban regeneration projects, the planning process would rarely open to residents [72]. However, citizen participation is heavily emphasized as the planning focuses on promoting social safety, facilities, local services and other public realms [86] because planning for social goals needs to meet the actual demands of citizens, or else it may not work.

\subsubsection{Place}

Degen and Garcia noted that political elites often ignore the influence of historicalgeographical characteristics of different areas and want to copy one area's mode of urban regeneration to the others [94]. However, sometimes the results and the effects may not turn out the way they expected due to differences in these areas. For example, although many governments encourage community engagement, in reality, in neighborhoods with large populations, it is likely to require significant costs and time to collect the opinions of residents and reach an agreement [29]. Likewise, the historical failure of multiple governance will hinder the collaboration among the stakeholders [45] because the unsuccessful participation history of actors will affect their trust in each other [65]. Another important element is social capital. According to Bull and Jones [95], local social capital can help connect central and local agencies, private sectors, voluntary organizations and community groups to advocate pluralistic participation, but the function of social capital depends on the predominant type. Besides the factors mentioned above, the location, the demographic structure, the development history, the culture and local business are also 
important historical-geographical characteristics $[47,74]$. Urban regeneration initiatives consist of various fragmented approaches of community or neighborhood regeneration, which will produce different forms and content of urban governance and regeneration in different places $[45,62]$.

\subsubsection{Person}

Hemphill found that the individual role has been ignored, although more and more studies have paid attention to partnerships [47]. These key individuals often significantly influence the URG mode and they can come from governments or communities, senior levels or street levels [65]. They always have distinctive characters and personalities, rich experiences and a breadth of relationships so that they can have a greater say and authority [39]. Van der Pennen and Van Bortel concluded four types of key individuals from civics: frontline workers, everyday fixers, social entrepreneurs and boundary spanners [85]. Frontline workers, as important networkers, keep connections with stakeholders and encourage citizens to engage in bureaucratic procedures. Everyday fixers are pragmatists and activists. They can negotiate with private and public actors smoothly and have a positive influence on other people. Social entrepreneurs can easily understand social reality from the view of the inhabitants and collect resources to start an initiative to promote the self-development of communities. Boundary spanners always have multiple identities and can help create networks and deal with conflicts between different groups. These four types of individuals above are conducive to promoting multi-stakeholder participation, especially citizen participation. However, if there is a strong leader, the governance mode may become different. In the cases studied by Sagan and Grabkowska [70] and Boisseuil [39], the government governance dominates the urban regeneration because the city's leader is an autocrat who will exclude voices different from theirs.

\section{Discussions and Findings}

\subsection{Communication, Collaboration and Accountability of URG}

No matter what kinds of modes are implemented in urban regeneration, communication and collaboration are unavoidable challenges. Any URG mode includes internal and external communication and collaboration. Taking government governance as a case, there are two outstanding internal issues, the balance between national and local authorities and the synergy among cross sectors. Local governments often play an enforcer role in central-dominant urban regeneration initiatives. However, in reality, central decisions cannot be effectively implemented sometimes [90]. On the one hand, the information is not accurate because the delivery may pass through various administrative levels. On the other hand, the local authorities are unwilling to do due to limited resources. In terms of the synergy among cross sectors, Boisseuil stated that the disagreement easily happens between administrators who come from diverse departments [39], and this also occurs in entrepreneurial governance and civic governance. Under the entrepreneurial governance mode, conflicts and confrontation are more frequent between public and private sectors because of different goals, interests and values. The complexity of the communication and collaboration is increased, as well. When thousands of citizens are also involved, coming to an agreement is difficult enough before thinking about the conflicts among the various interest groups.

In order to reduce the conflicts in communication and collaboration and achieve a balance of multiple targets, many studies have proposed "accountability" to clarify the boundary and responsibility of various actors [96,97]. Whatever kinds of URG modes are adopted, there are many accountor-accountee relationships between the stakeholders. Governments always play an accountor role in providing public services to citizens. However, in urban regeneration projects with a public-private partnership, governments also act as accountees to supervise the accountors. The instruments and measures to control the implementation of the accountor by the accountee are accountability mechanisms [20]. For example, citizens can know the accountable office holders and evaluate them or remove 
them from office by some procedures and rules. Likewise, the government can use some indicators to check the performance and outcomes of parts of enterprises; enterprises also can check the responsibility of governments by some contract agreements. However, accountability is often ignored by actors and the accountability measures are still limited.

\subsection{Governance Arrangement Is Changeable and Need a Clear Value Orientation}

This paper only summarized URG modes into three categories. However, many submodes are gradually emerging due to the adjustment of the arrangement of partner, power and procedure in different urban regeneration activities. As mentioned in Figure 5, civic governance includes social group governance and community governance. Community governance can also be divided into seven types [81]. Even so, there is no perfect mode to match with all the situations [25]. Beauregard said the partnerships are "historical chameleons" changed as often as the development of economy, policy and society, just like these three modes have emerged step-by-step in different historical stages [98]. It seems that the emergence of a new URG mode is to deal with the problems that the old mode cannot solve. For example, Dargan said community participation is regarded as a good remedy for previous failure [83]. Even so, it does not mean that the new URG mode is much better than the old one. In recent years, civic participation was overrated. Sometimes, to echo the political value of central government, the public officers vigorously pursued resident engagement without considering the local situation. Many resources were spent with little effect. In fact, each URG mode has its pros and cons, which are discussed in our analysis. An appropriate mode is the best one.

How can we understand the "appropriateness" of governance arrangement? This paper argues that the appropriate governance arrangement should align with the core value of urban regeneration. That is, clear value orientation is one of the preconditions of developing a proper URG arrangement. As we mentioned above, URG is not value-neutral and it is hard to balance multiple goals and conflicts. For example, if urban regeneration initiatives focus more on economic achievements, empowering private sectors can help boost capital efficiency. On the contrary, if reducing social exclusion, activating citizens, and improving public services are the main goals, it should empower citizens to dominate decision-making. From the perspective of the evolution of URG, the value orientation of government governance is control, consolidating power and efficiency, and the value orientation of entrepreneurial governance is economic growth, development and profits, and the value orientation of civic governance are people, democracy and equality. Value orientation has an important influence on urban development strategies, thus further influencing the function and objectives of different urban regeneration projects.

\subsection{There Is a Basic Analysis Framework of Developing URG Arrangements: A $8 p$ Model}

According to the analysis of this paper, a basic analysis framework of URG can be drawn, named the " $8 \mathrm{p}$ model" (Figure 6). The $8 \mathrm{p}$ model consists of three circles. The first circle is an influential factor circle. The decision makers can clarify the goals, resources and barriers by analyzing the plan, place and person of urban regeneration activities. The second circle is an element circle. The differences among various governance arrangements depend on three important elements: the partner, the power of each partner, the procedure the partner is involved in. The influential circle influences the element circle. By comprehensively considering three influential factors, an appropriate governance arrangement of partner, power and procedure can be proposed. The third circle is a policy circle. The policies aim to enhance the legitimacy of URG, specify the details of URG and promote the implementation of the URG. This $8 p$ model can be seen as a guideline for developing appropriate governance arrangements. 


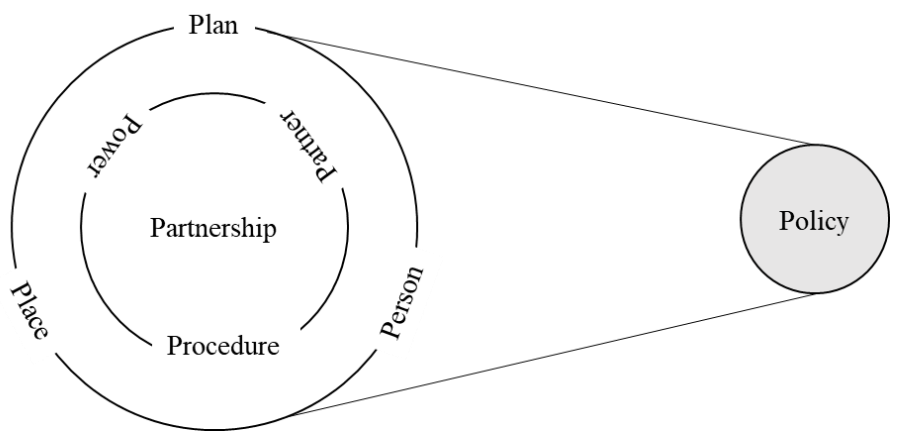

Figure 6. An 8p model of URG.

In general, URG can be divided into two dimensions: city and project. In different dimensions, the $8 \mathrm{p}$ model has different keywords (see Table 3 ). In the city dimension, URG aims to decide the future direction, area, policy, master plan and regulation of all urban regeneration activities. Thus, the plan is a comprehensive vision of urban regeneration. The urban regime, political culture and the urban entire economic and social development as the important place elements that influence plan, person, partner and power distribution. With the popularity of new ideas such as "people-centered" and "sustainable development" [99,100], in the city dimension, urban governance has transformed from unitary governance into multiple governance. Under this situation, governments are more inclusive to other urban stakeholders and organize many opportunities for various partners to propose their opinions, suggestions and complaints. They stand for or against any ideas of urban affairs, such as hearings. However, if the other stakeholders want to gain actual power, they need some outstanding representatives to fight for rights. Most of them are party leaders, business leaders or professionals. Then they can influence the participation procedure and the policy making. The interaction among the " $8 \mathrm{p}$ " is shown in Figure 7.

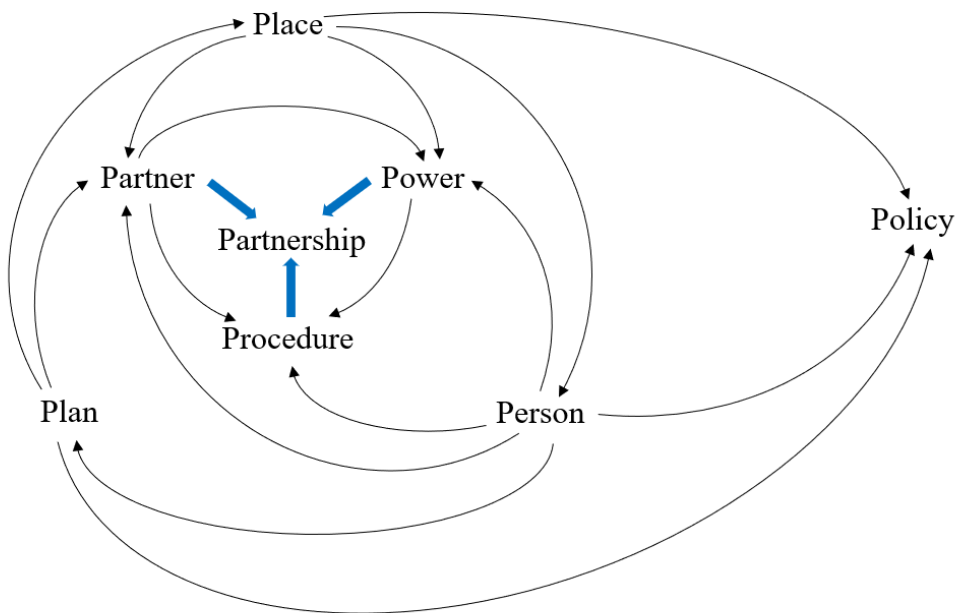

Figure 7. The connection among the " $8 \mathrm{p}$ ".

In the project dimension, although the interaction among " $8 \mathrm{p}$ " is similar to that in the city dimension, the keywords of " $8 \mathrm{p}$ " are different. Each project has its own objectives and highlights which follow the comprehensive vision but focus on some aspects. Therefore, the governance arrangements of urban regeneration projects are more diverse and easily influenced by place and person. Place elements, such as local history and culture, social network and capital and the situation of buildings and infrastructures, determine whether it is capable and possible to encourage multiple partner participation. Likewise, the capability, knowledge, insight and social relationships of important persons will influence the power distribution, procedure arrangement and the actual participation of different partners. 
In the project dimension, the policies refer to the action plans and rules in contracts. In general, the rules and actions are always controlled by real powerful partners and people.

Table 3. The keywords of the $8 \mathrm{p}$ model in different levels.

\begin{tabular}{|c|c|c|c|c|c|c|c|}
\hline Level & Plan & Place & Person & Partner & Power & Procedure & Policy \\
\hline City & $\begin{array}{l}\text { comprehensive } \\
\text { vision }\end{array}$ & $\begin{array}{c}\text { urban regime } \\
\text { and political } \\
\text { culture } \\
\text { urban entire } \\
\text { economic and } \\
\text { social } \\
\text { development }\end{array}$ & $\begin{array}{c}\text { mayor } \\
\text { party leaders } \\
\text { business } \\
\text { leaders } \\
\text { civic leaders } \\
\text { professionals }\end{array}$ & $\begin{array}{l}\text { government } \\
\text { enterprises } \\
\text { citizens } \\
\quad \text { other } \\
\text { organizations } \\
\text { such as NGO, } \\
\text { media }\end{array}$ & $\begin{array}{l}\text { give opinions } \\
\text { and } \\
\text { suggestions } \\
\text { approval and } \\
\text { approval } \\
\text { decision- } \\
\text { making }\end{array}$ & $\begin{array}{l}\text { scoping } \\
\text { planning } \\
\text { financing }\end{array}$ & $\begin{array}{l}\text { strategical } \\
\text { development } \\
\text { policies } \\
\text { related } \\
\text { regulations } \\
\text { and laws } \\
\text { guideline }\end{array}$ \\
\hline Project & $\begin{array}{l}\text { objectives } \\
\text { and } \\
\text { highlights }\end{array}$ & $\begin{array}{l}\text { local history } \\
\text { and culture } \\
\text { social network } \\
\text { and social } \\
\text { capital } \\
\text { buildings and } \\
\text { infrastructure }\end{array}$ & $\begin{array}{l}\text { public officials } \\
\text { investor, } \\
\text { designers, } \\
\text { contractors and } \\
\text { project } \\
\text { managers } \\
\text { residents }\end{array}$ & $\begin{array}{l}\text { government } \\
\text { design } \\
\text { company } \\
\text { contractor } \\
\text { developer } \\
\text { related citizens } \\
\text { community } \\
\text { other } \\
\text { organizations } \\
\text { such as NGO, } \\
\text { media }\end{array}$ & $\begin{array}{l}\text { implementation } \\
\text { give opinions } \\
\text { and } \\
\text { suggestions } \\
\text { complaints and } \\
\text { negotiation } \\
\text { decision- } \\
\text { making } \\
\text { payment or } \\
\text { requiring } \\
\text { compensation }\end{array}$ & $\begin{array}{l}\text { planning } \\
\text { financing } \\
\text { implementation }\end{array}$ & $\begin{array}{l}\text { rules on } \\
\text { contracts } \\
\text { action plan }\end{array}$ \\
\hline
\end{tabular}

\section{Conclusions and Avenues for Future}

By valuable selected and reviewed papers, this paper defined URG, analyzed its signature elements, compared different URG modes and refined the factors influencing their practices. The comprehensive review provided a simple but comprehensive understanding of URG. As a decision mode or partnership, URG consists of the partner, the power and the procedure. It is influenced by the plan, the place, and the person. There are no perfect modes because different URG modes have pros and cons. Communication and collaboration are common challenges in each URG mode. Therefore, accountability needs to be emphasized in the design of URG modes. According to the analysis of this paper, an $8 \mathrm{p}$ model can be proposed to describe the meta-governance of URG.

Urban regeneration has become normalized in global urban development. Thus, URG also becomes an important issue of urban management. As a microcosm of urban governance and public administration, URG is widely related to the economic, political, and social fields. However, empirical studies are still limited and focus more on developed countries. Moreover, the academic research of URG has been lagging behind the practice of URG. Therefore, this paper advocates establishing URG as a distinct research area and proposes four research directions.

- Future research should investigate cases from different countries with different regimes, economic conditions and locations. The case study is a very effective research method to analyze URG development. Diverse cases are better for theory building. Currently, however, a large number of cases mainly come from Europe and the US. Thus, it is difficult to comprehensively understand URG.

- Future research should clarify the details of the factors influencing the practices of URG. In previous studies, most of them found some influential factors but did not conduct deep research. Therefore, it is necessary to explore the degree of influence that different factors can exert on URG under various situations. The results can contribute to the selection of URG modes.

- Future research should adopt more quantifiable approaches to conduct decisionmaking about URG. Whether practices or academic research, we often advocated learning experiences from other urban regeneration activities. However, it is difficult 
to find similar and matchable cases that are demonstrated as good practices, so concluding experiences from the practices and transforming the results to a quantifiable approach is very significant.

- Finally, more research of sub-topics of URG should be conducted, as well. Although some sub-topics of URG have been studied, many of them still lack wide attention, such as the longitudinal impacts of URG on the economy, society, and environment, the quantitative evaluation of URG and the transformation and evolution of URG.

Author Contributions: Conceptualization, F.X. and G.L.; methodology, F.X.; formal analysis, F.X.; data curation, F.X. and G.L.; writing — original draft preparation, F.X.; writing-review and editing, G.L., T.Z., F.X.; funding acquisition, G.L. All authors have read and agreed to the published version of the manuscript.

Funding: This research was funded by the Fundamental Research Funds for the Central Universities (No. 2020CDJSK03PT23).

Conflicts of Interest: The authors declare no conflict of interest.

Appendix A

Table A1. Selection of broad urban regeneration definitions, sorted by year of publication.

\begin{tabular}{lll}
\hline \multicolumn{1}{c}{ Study } & Year & \multicolumn{1}{c}{ Definition } \\
\hline & & $\begin{array}{l}\text { In this sense, urban regeneration can be seen as a way of providing desirable } \\
\text { outcomes such as: more intensive use of areas with the availability of good } \\
\text { infrastructure, services, and jobs; avoidance of speculative retention of unused real } \\
\text { estate properties; reduction of social and spatial inequalities between different areas } \\
\text { of the city; balanced distribution of costs and benefits in the urbanization process; } \\
\text { socialization of gains associated with urban surplus values. (p. 1133) }\end{array}$ \\
$\begin{array}{l}\text { Pereira [32] } 2019 \\
\text { santos }\end{array}$ \\
\hline
\end{tabular}

De Medici et al. [84] $2018 \quad \begin{aligned} & \text { Urban regeneration is a process aimed at improving settlements qualities and } \\ & \text { creating the conditions for a sustainable and social inclusive growth. (p. 1) }\end{aligned}$

Precinct regeneration involves land amalgamation, which guarantees a larger scale of residential redevelopment and which can arguably sustain the basis for a strategic regeneration; allowing state and local governments the opportunity to: (p. 364)

- Achieve greater densities, through the construction of denser housing typologies.

- Provide a greater diversity of housing, targeting a wider variety of housing

Glackin and Dionisio [34]

2016 submarkets.

- Provide additional urban amenities, such as walkways, parks and services.

- $\quad$ Reduce infrastructural redundancy, e.g., construction of driveways, canopy trees, and turning circles.

- Implement better stormwater management, through the construction of more permeable surfaces.

- Retrofit larger areas with sustainable infrastructure, such as water capture, distributed energy systems, and composting.

Urban regeneration can be seen as a comprehensive and integrated vision and action which leads to the resolution of urban problems and which seeks to bring about a lasting improvement in the economic, physical, social and environmental condition of an area that has been subject to change. (p. 245)

Urban regeneration, like its utopian Garden Cities precedents (Howard, 1902), extends beyond narrow economic development or physical urban renewal. Its Huston et al. [62] proximate pragmatic physical, economic, or environmental upgrades improve the daily lives of ordinary people. Within financial constraints and realistic limits, sustainable regeneration improves places, stimulates prosperity, and fosters inclusive local capabilities. (p. 72) 
Table A1. Cont.

\begin{tabular}{cll}
\hline \multicolumn{1}{c}{ Study } & Year & \multicolumn{1}{c}{ Definition } \\
\hline Parés et al. [45] & 2014 & $\begin{array}{l}\text { Regeneration policies encompass not only the physical and the economic aspects of } \\
\text { urban transformation, but that they also integrate the social dimension, placing a } \\
\text { particular emphasis on the right of the residents to stay in the area and to improve } \\
\text { their life-conditions. (p. 3253) }\end{array}$ \\
\hline Zhou [101] & $\begin{array}{l}\text { Regeneration could be a positive solution to deal with such urban decline, decay or } \\
\text { transformation. (p. 298) } \\
\text { Urban regeneration aims to revitalize urban functions in a positive and balanced } \\
\text { manner to achieve sustainable outcome of urban development. (p. 298) }\end{array}$ \\
\hline
\end{tabular}

Regeneration should be seen as a multidimensional and multifaceted process aimed at improving the quality of the urban fabric and the natural environment as well as Schenkel [25] reconstructing the local economy. Urban regeneration must concentrate on integrating social and economic goals. (p. 73)

Today, the actors understand neighborhood regeneration as a combination of the functional logic (hardware and economic interventions) and the emotional logic (software interventions). (p. 84)

Urban regeneration processes are processes that refer to vision and action building

Van Meerkerk et al. [31]

2013

Kort and Klijn [23]

2013

Parés et al. [93]

2011 aimed to resolve urban issues and to bring about sustainable improvement in the economic, physical, social and/or environmental conditions of an urban area that has been subject to change (Roberts, 2000, p. 17). (p. 1630)

Urban regeneration is always an area where we find complex decision making among a wide variety of actors. (p. 92)

Urban regeneration, as an emerging and innovative area within urban planning policy, can be defined as a comprehensive, integrated vision that leads to the Pares et al. [9] resolution of urban problems and aims to achieve improvements in the economic, physical, social and environmental conditions of the area that is being transformed (Roberts and Sykes 2006, 17). (p. 242)

The regeneration of shrinking cities and the associated development of new futures

Liebmann and Kuder [102]

2012 for these cities must be understood as part of a long process, in which many paths of development can emerge through the long selection process, as each competes for acknowledgement, attention and limited financial resources. (p. 1158)

\begin{tabular}{ll}
\hline Pollock and Sharp [24] $2012 \quad \begin{array}{l}\text { That regeneration is a long-term and costly endeavor requiring the continuance of } \\
\text { expertise and the establishment of trust. (p. 3076) }\end{array}$ \\
\hline
\end{tabular}

Savini [87]

2010

Neighborhood regeneration is not an ordinary intervention that takes place across

(p. 961)

Jones and Evans [35]

2006

Urban regeneration is characterized by collaboration between organizations with different qualities, motivations and resources to tackle projects at larger spatio-temporal scale. (p. 1491)

Ball and Maginn [56]

2005

In its broadest terms, urban regeneration refers to policies directed at tackling social, economic, physical and environmental problems within inner-city areas. (p. 25)

The meaning of regeneration in Britain has widened since the early 1990s, when it

Davies [28]

2002 was associated mainly with economic and infrastructural development. It is now an umbrella term understood as the promotion of the social, economic and environmental well-being of an area. (p. 307)

Regeneration schemes focused on physical and economic outcomes the reclamation of derelict land, the provision of new infrastructure and wealth creation. Social
deprivation would, it was claimed, be solved indirectly as the benefits of new

Foley and Martin [29]

2000 economic activity trickled down to the unskilled, low paid and unemployed. (p. 481) 


\section{Appendix B}

Table A2. Selection of broad governance definitions, sorted by year of publication.

\begin{tabular}{lll}
\hline \multicolumn{1}{c}{ Study } & Year & \multicolumn{1}{c}{ Definition } \\
\hline Atkinson et al. [38] 2019 & $\begin{array}{l}\text { Governance, for us, refers to changes in the institutional arrangements that have developed } \\
\text { to coordinate the activities of a range of organizations / actors involved in governing a } \\
\text { society (Newman, 2001, p. 26) and in relation to specific policies and programs. (p. 1085) }\end{array}$ \\
\hline Boisseuil [39] & $2019 \quad \begin{array}{l}\text { Governing therefore means understanding the principles and modes of action of all of the } \\
\text { actors involved in the policy process. (p. 427) } \\
\text { Separate units administer each policy and have the power to shape their own domains. } \\
\text { Governance refers to the power over the implementation of each of them. (p. 428) }\end{array}$ \\
\hline Vale [21] 2018 & $\begin{array}{l}\text { Governance, in these contexts, represents the confluence of contending authorities vying for } \\
\text { influence over neighborhood investment. (p. 445) }\end{array}$ \\
\hline & $\begin{array}{l}\text { Proper governance reduces financial manipulation or fiscal distortion and incentivizes } \\
\text { projects with conservation, education, or health spinoffs. It comprises the formal policies, } \\
\text { procedures, and informal culture and norms to focus corporate activity and attenuate } \\
\text { agency problems (corruption, nepotism or free-riding). Institutional fit, good governance } \\
\text { and authentic consultation mitigates the risk of outlandish projects, fanciful projections, and } \\
\text { cost blowouts. (p. 70) }\end{array}$
\end{tabular}
cost blowouts. (p. 70)

\begin{tabular}{|c|c|c|}
\hline Gopakumar [48] & 2014 & $\begin{array}{l}\text { Good governance, however, is not a monolith but is itself an aggregate, assembled, for } \\
\text { instance, by deploying technologies of conditionality, ownership and legality (Anders 2008, } \\
\text { 2010). (p. 95) }\end{array}$ \\
\hline Wallace [103] & 2010 & $\begin{array}{l}\text { For the purposes of this article we refer to it as a mode of governing practice in which the } \\
\text { state is only one participant in self-organized, subnational or local policy arenas alongside } \\
\text { actors from civil society and the for-profit sector. (p. 806) }\end{array}$ \\
\hline $\begin{array}{l}\text { Aalbers and Van } \\
\text { Beckhoven [46] }\end{array}$ & 2010 & $\begin{array}{l}\text { In other words, governance is more than a trend in which government increasingly involves } \\
\text { organizations outside government it also demands a shift in the way government } \\
\text { bureaucracies are managed. (p. 451) }\end{array}$ \\
\hline Tasan-Kok [37] & 2010 & $\begin{array}{l}\text { Governance is a process of coordinating political decision-making (DiGaetano \& Strom } \\
\text { 2003), as well as the actors, social groups, institutions in a particular institutional context } \\
\text { (Melo \& Baiocchi 2006) to attain appropriate goals that have been discussed and collectively } \\
\text { defined in the fragmented, uncertain environments (LeGales 1998, 2001). (p. 129) }\end{array}$ \\
\hline $\begin{array}{l}\text { Jones and } \\
\text { Evans [35] }\end{array}$ & 2006 & $\begin{array}{l}\text { Governance by government sees the state as the primary agency for delivery of services, } \\
\text { with little or no interaction between government and businesses. Governance by } \\
\text { partnership sees local partnerships forming between government and business, but purely } \\
\text { as mechanisms for delivering government policy. The third tier identified is described as } \\
\text { governance by regime, where government and the private sector work together in } \\
\text { long-term, synergistic networks that develop spontaneously, rather than in response to a } \\
\text { policy initiative. (p. 1493) }\end{array}$ \\
\hline Bull and Jones [95] & 2006 & $\begin{array}{l}\text { The shift from government to governance refers to a move away from centralized and } \\
\text { hierarchical structures of government towards a collaborative approach with social agencies } \\
\text { and non-governmental actors, including the private sector. (p. } 769 \text { ) }\end{array}$ \\
\hline Whitehead [104] & 2002 & $\begin{array}{l}\text { In this paper governance is understood as a process whereby formal governing structures } \\
\text { are no longer focused primarily on the political realms of public sector government } \\
\text { (parliament, town/city hall, civil servants), but are increasingly incorporating a range of } \\
\text { interests drawn also from the private sector and civil society. (p. 7) }\end{array}$ \\
\hline Davies [28] & 2002 & $\begin{array}{l}\text { Stoker (1998, p. 19) defines it simply, as a complex set of institutions and actors that are } \\
\text { drawn from but also beyond government. (p. 303) }\end{array}$ \\
\hline
\end{tabular}




\section{Appendix C}

Table A3. Selection of broad urban governance definitions, sorted by year of publication.

\begin{tabular}{lll}
\hline \multicolumn{1}{c}{ Study } & Year & \multicolumn{1}{c}{ Definition } \\
\hline Vale [21] & 2018 & $\begin{array}{l}\text { The concept of urban governance characterizes the different blends of decision makers in } \\
\text { each city. (p. 433) }\end{array}$ \\
\hline $\begin{array}{l}\text { Teernstra and } \\
\text { Pinkster [81] }\end{array}$ & $\begin{array}{l}\text { Thereby, neighborhood governance has become a form of governance-beyond-the-state } \\
\text { (Swyngedouw 2005), which “... moves away from fixed ideas about power as a } \\
\text { commodity rooted in particular institutions to more fluid ideas of power developed and } \\
\text { negotiated between partners (Taylor 2007, p. 299). (p. 58) }\end{array}$
\end{tabular}

While the techno-managerial approach portrays urban governance as a technical exercise that needs to be streamlined in the interest of efficiency and productivity, the democratic narrative frames urban governance as an outcome of a messy and informal negotiation Gopakumar [48] $2014 \quad$ resting upon a substrate of dense social and political networks. (p. 90) Urban governance is here understood as a managerial exercise whereby resources and services can be provided through as efficient a process as possible. Good urban governance thus combines a managerial orientation to governing cities with specific technologies of governmentality. (p. 95)

Urban governance is supposed to be evolving towards more cooperative ways of urban

Parés et al. [45] $2014 \quad$ policy-making that strengthen the weight of the private sector in public decision-taking. (p. 3251)

There is no ideal model of urban and regional governance, but it is clear that improving governance in urban regions is not just about reforming institutions. It is also about Schenkel [25] $2013 \quad$ changing attitudes, the culture of governance and questions of identity. Good urban governance is understood as a political task to redirect traditional values into knowledge-based actor networks. (p. 74)

Medina [22]

In fact, some authors (Rodriguez, Moulaert and Swyngedouw, 2001) argue that the term urban governance refer to the increasing complexity of public intervention in the city. (p. 367)

Uršič and

Križnik [72]

Biddulph [44]

2011

Aalbers and Van

Beckhoven [46]

Breda-Vázquez et al. [51]
Kearns and Paddison (2000, p. 847) state that urban governance is not an attempt to regain control so much as an attempt to manage and regulate difference and to be creative in urban arenas which are themselves experiencing considerable change. (p. 26)

Hubbard (1996, p. 1441) suggests that " the focus of much urban governance is no longer the provision of services to city residents, but a concern with the prosperity of the city and its ability to attract jobs and investment." (p. 64)

Urban governance can be and has been viewed in many different ways, but it usually includes at least some of the following elements: financial decentralization, political decentralization, empowerment and participation of citizens as well as civic and social groups, and finally, accountability and transparency including openness of procedures (UNCHS 1999). (p. 450)

For example, in the context of the UK, Kearns and Turok (2000) argue that Urban governance arrangements are not solely about the emergence of coalitions with power to achieve certain ends. They also reflect the power that central government continues to exercise over local arrangements. (p. 2219)

To some extent, it could be argued that urban governance is just a new phraseology encapsulating previous discourses such as 'corporate thinking', 'public management', 'political systems' and 'strategic planning'. (p. 59) 


\section{Appendix D}

Table A4. The emphasis of signature elements and influential factors in selected articles.

\begin{tabular}{|c|c|c|c|c|c|c|c|}
\hline Author & Year & Place & Person & Plan & Partner & Power & Procedure \\
\hline Martins and Santos Pereira [32] & 2019 & & & * & * & & * \\
\hline Kim [82] & 2019 & * & * & & & * & \\
\hline Atkinson et al. [38] & 2019 & * & * & * & & & * \\
\hline Boisseuil [39] & 2019 & * & * & * & * & * & * \\
\hline Seo and Joo [105] & 2019 & * & & & & & * \\
\hline Tasan-Kok et al. [20] & 2019 & & & & * & & \\
\hline Zhong and Leung [60] & 2019 & * & & & * & & * \\
\hline Vale [21] & 2018 & * & * & & * & & \\
\hline Farhat [58] & 2018 & & & * & * & * & \\
\hline Newman et al. [63] & 2018 & & & & * & & \\
\hline De Medici et al. [84] & 2018 & * & & & * & & \\
\hline Kleinhans [90] & 2017 & * & & & * & * & \\
\hline Vento [77] & 2017 & & & * & * & * & \\
\hline Bruce and Clarson [59] & 2017 & * & & & * & & \\
\hline Clemente and Salvati [74] & 2017 & * & & & & & \\
\hline Glackin and Dionisio [34] & 2016 & * & & & * & & * \\
\hline Tan and Altrock [19] & 2016 & & & * & * & & * \\
\hline Huston et al. [62] & 2015 & * & * & & & & \\
\hline Teernstra and Pinkster [81] & 2015 & & & & * & * & * \\
\hline $\begin{array}{l}\text { Van der Pennen and Van } \\
\text { Bortel [85] }\end{array}$ & 2015 & & * & & * & & \\
\hline Ángeles Huete Garcia et al. [92] & 2015 & * & & & & & \\
\hline Gopakumar [48] & 2014 & & & * & & & \\
\hline Parés et al. [45] & 2014 & * & & & & & \\
\hline Zhou [101] & 2014 & & & & * & * & \\
\hline Schenkel [25] & 2013 & * & & * & & & \\
\hline Dicks [91] & 2013 & * & & & * & & * \\
\hline Medina [22] & 2013 & & & * & & & \\
\hline Van Meerkerk et al. [31] & 2013 & * & & & * & & * \\
\hline Cocks [106] & 2013 & & * & & & & \\
\hline Bacqué and Biewener [97] & 2013 & * & & & * & * & \\
\hline Kort and Klijn [23] & 2013 & & & & * & * & \\
\hline Sagan and Grabkowska [70] & 2012 & * & & * & & * & \\
\hline Degen and Garcia [94] & 2012 & * & & & & & \\
\hline Liebmann and Kuder [102] & 2012 & * & & * & & & \\
\hline $\mathrm{Li}[55]$ & 2012 & & & & * & * & * \\
\hline Uršič and Križnik [72] & 2012 & & * & * & & & * \\
\hline Keresztély and Scott [107] & 2012 & & & & * & & \\
\hline Fuller [73] & 2012 & & & * & & * & \\
\hline Pollock and Sharp [24] & 2012 & * & & & * & * & * \\
\hline Lawless [53] & 2012 & * & & & * & & \\
\hline Parés et al. [93] & 2011 & * & & * & & * & \\
\hline Kort and Klijn [79] & 2011 & & & & * & * & * \\
\hline Savini [87] & 2010 & & & & * & * & * \\
\hline Fallov [13] & 2010 & * & & & * & & \\
\hline Mullins and Bortel [86] & 2010 & * & & & & & \\
\hline Aalbers and Van & 2010 & & & & & * & \\
\hline Beckhoven [46] & 2010 & & & & & 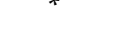 & \\
\hline Tasan-Kok [37] & 2010 & * & & * & & * & \\
\hline Kuyucu and Ünsal [68] & 2010 & * & & & & * & \\
\hline Ruming et al. [108] & 2010 & * & & & * & & \\
\hline Beatty et al. [109] & 2010 & * & & * & & * & \\
\hline Lawson and Kearns [64] & 2009 & & & * & & * & * \\
\hline Van Bortel et al. [66] & 2009 & & & & * & * & \\
\hline Van Bortel and Mullins [110] & 2009 & & & * & * & * & \\
\hline
\end{tabular}


Table A4. Cont.

\begin{tabular}{|c|c|c|c|c|c|c|c|}
\hline Author & Year & Place & Person & Plan & Partner & Power & Procedure \\
\hline Bernt [76] & 2009 & * & & & & & \\
\hline Lin and Hsing [111] & 2009 & * & & & * & & \\
\hline Breda-Vázquez et al. [51] & 2009 & & & & * & * & * \\
\hline Haffner and Elsinga [112] & 2009 & & & * & * & & * \\
\hline Dargan [83] & 2009 & & & & & & * \\
\hline Osei [113] & 2009 & & & & & & \\
\hline Jonas and McCarthy [57] & 2009 & & & * & & & \\
\hline Muir and Rhodes [65] & 2008 & & & * & & * & * \\
\hline North and Syrett [114] & 2008 & * & & & & & \\
\hline Díaz Orueta [115] & 2007 & * & & & * & & \\
\hline Card and Mudd [116] & 2007 & * & & & & & \\
\hline Hemphill et al. [47] & 2006 & * & * & * & * & * & \\
\hline Jones and Evans [35] & 2006 & & & & & * & \\
\hline Bull and Jones [95] & 2006 & * & & & & * & \\
\hline Hull [117] & 2006 & & & & & * & \\
\hline Ball and Maginn [56] & 2005 & * & & & * & * & \\
\hline Johnson and Osborne [118] & 2003 & & & * & & & \\
\hline McGuirk [119] & 2000 & & & & & * & \\
\hline Foley and Martin [29] & 2000 & & & & * & & \\
\hline Ward [67] & 1997 & * & & & & & \\
\hline Raco [120] & 1997 & * & & & * & & \\
\hline Imrie et al. [121] & 1995 & * & & & & & \\
\hline
\end{tabular}

\section{References}

1. Pérez, M.G.R.; Laprise, M.; Rey, E. Fostering sustainable urban renewal at the neighborhood scale with a spatial decision support system. Sustain. Cities Soc. 2018, 38, 440-451. [CrossRef]

2. Forouhar, A.; Hasankhani, M. Urban Renewal Mega Projects and Residents' Quality of Life: Evidence from Historical Religious Center of Mashhad Metropolis. J. Urban Health 2018, 95, 232-244. [CrossRef] [PubMed]

3. Berta, M.; Bottero, M.C.; Ferretti, V. A mixed methods approach for the integration of urban design and economic evaluation: Industrial heritage and urban regeneration in China. Environ. Plan. B Urban Anal. City Sci. 2018, 45, 208-232. [CrossRef]

4. Zhuang, T.; Qian, Q.K.; Visscher, H.J.; Elsinga, M.G. Stakeholders' Expectations in Urban Renewal Projects in China: A Key Step towards Sustainability. Sustainability 2017, 9, 1640. [CrossRef]

5. Wang, H.; Zhao, Y.; Gao, X.; Gao, B. Collaborative decision-making for urban regeneration: A literature review and bibliometric analysis. Land Use Policy 2021, 107, 105479. [CrossRef]

6. Zhu, S.; Li, D.; Jiang, Y. The impacts of relationships between critical barriers on sustainable old residential neighborhood renewal in China. Habitat Int. 2020, 103, 102232. [CrossRef]

7. Martinat, S.; Navratil, J.; Hollander, J.B.; Trojan, J.; Klapka, P.; Klusacek, P.; Kalok, D. Re-reuse of regenerated brownfields: Lessons from an Eastern European post-industrial city. J. Clean. Prod. 2018, 188, 536-545. [CrossRef]

8. Mehanna, W.A.E.-H.; Mehanna, W.A.E.-H. Urban renewal for traditional commercial streets at the historical centers of cities. Alex. Eng. J. 2019, 58, 1127-1143. [CrossRef]

9. Lai, L.W.C.; Chau, K.W.; Cheung, P.A.C.W. Urban renewal and redevelopment: Social justice and property rights with reference to Hong Kong's constitutional capitalism. Cities 2018, 74, 240-248. [CrossRef]

10. Manupati, V.K.; Ramkumar, M.; Samanta, D. A multi-criteria decision making approach for the urban renewal in Southern India. Sustain. Cities Soc. 2018, 42, 471-481. [CrossRef]

11. Dixon, T. What impacts are emerging from Covid-19 for urban futures? In The Centre for Evidence-Based Medicine; University of Oxford: Oxford, UK, 2020.

12. Gu, T.; Li, D.; Zhu, S.; Wang, Y. Does sponge-style old community renewal lead to a satisfying life for residents? An investigation in Zhenjiang, China. Habitat Int. 2019, 90, 102004. [CrossRef]

13. Fallov, M.A. Community Capacity Building as the Route to Inclusion in Neighbourhood Regeneration? Int. J. Urban Reg. Res. 2010, 34, 789-804. [CrossRef]

14. Alexandri, G.; Janoschka, M. Post-pandemic' transnational gentrifications: A critical outlook. Urban Stud. 2020, 57, 3202-3214. [CrossRef]

15. McGuirk, P.; Dowling, R.; Maalsen, S.; Baker, T. Urban governance innovation and COVID-19. Geogr. Res. 2020, 59, 188-195. [CrossRef]

16. Fabris, L.M.F.; Camerin, F.; Semprebon, G.; Balzarotti, R.M. New Healthy Settlements Responding to Pandemic Outbreaks Approaches from (and for) the Global City. Plan J. 2020, 5, 385-406. 
17. Mueller, N.; Rojas-Rueda, D.; Khreis, H.; Cirach, M.; Andrés, D.; Ballester, J.; Bartoll, X.; Daher, C.; Deluca, A.; Echave, C.; et al. Changing the urban design of cities for health: The superblock model. Environ. Int. 2020, 134, 105132. [CrossRef] [PubMed]

18. Liu, G.; Yi, Z.; Zhang, X.; Shrestha, A.; Martek, I.; Wei, L. An Evaluation of Urban Renewal Policies of Shenzhen, China. Sustainability 2017, 9, 1001. [CrossRef]

19. Tan, X.; Altrock, U. Struggling for an adaptive strategy? Discourse analysis of urban regeneration processes-A case study of Enning Road in Guangzhou City. Habitat Int. 2016, 56, 245-257. [CrossRef]

20. Tasan-Kok, T.; Hurk, M.V.D.; Özogul, S.; Bittencourt, S. Changing public accountability mechanisms in the governance of Dutch urban regeneration. Eur. Plan. Stud. 2019, 27, 1107-1128. [CrossRef]

21. Vale, L.J. Cities of stars: Urban renewal, public housing regeneration, and the community empowerment possibility of governance constellations. Int. J. Urban Sci. 2018, 22, 431-460. [CrossRef]

22. Medina, J.S. Urban Governance, Competitiveness and Renewal Process in the Medium-Sized Spanish Cities. Bol. Asoc. Geogr. Esp. 2013, 61, 367-372.

23. Kort, M.; Klijn, E.-H. Public-Private Partnerships in Urban Regeneration: Democratic Legitimacy and its Relation with Performance and Trust. Local Gov. Stud. 2013, 39, 89-106. [CrossRef]

24. Pollock, V.L.; Sharp, J. Real Participation or the Tyranny of Participatory Practice? Public Art and Community Involvement in the Regeneration of the Raploch, Scotland. Urban Stud. 2012, 49, 3063-3079. [CrossRef]

25. Schenkel, W. Regeneration Strategies in Shrinking Urban Neighbourhoods-Dimensions of Interventions in Theory and Practice. Eur. Plan. Stud. 2013, 23, 69-86. [CrossRef]

26. Camerin, F. From "Ribera Plan" to "Diagonal Mar", passing through 1992 "Vila Olímpica". How urban renewal took place as urban regeneration in Poblenou district (Barcelona). Land Use Policy 2019, 89, 104226. [CrossRef]

27. Grebler, L. Urban Renewal in European Countries. J. Am. Inst. Plan. 1962, 28, 229-238. [CrossRef]

28. Davies, J.S. The governance of urban regeneration: A critique of the 'governing without government' thesis. Public Adm. 2002, 80, 301-322. [CrossRef]

29. Foley, P.; Martin, S. A new deal for the community? Public participation in regeneration and local service delivery. Policy Politics 2000, 28, 479-492. [CrossRef]

30. Lees, L.; Phillips, M. Handbook of Gentrification Studies; Edward Elgar Publishing: Cheltenham, UK, 2018; 528p.

31. Van Meerkerk, I.; Boonstra, B.; Edelenbos, J. Self-Organization in Urban Regeneration: A Two-Case Comparative Research. Eur. Plan. Stud. 2013, 21, 1630-1652. [CrossRef]

32. Martins, M.L.R.; Pereira, A.L.D.S. Urban Regeneration in the Brazilian urban policy agenda. Eur. Plan. Stud. 2019, 27, 1129-1145. [CrossRef]

33. Newton, P.; Murray, S.; Wakefield, R.; Murphy, C.; Khor, L.-A.; Morgan, T. Towards a new development model for housing regeneration in greyfield residential precincts. Ahuri Final Rep. 2011, 171, 1-142.

34. Glackin, S.; Dionisio, M.R. 'Deep engagement' and urban regeneration: Tea, trust, and the quest for co-design at precinct scale. Land Use Policy 2016, 52, 363-373. [CrossRef]

35. Jones, P.; Evans, J. Urban regeneration, governance and the state: Exploring notions of distance and proximity. Urban Stud. 2006, 43, 1491-1509. [CrossRef]

36. Mark, B. Governance. In Encyclopedia Britannica; Britannica: Chicago, IL, USA, 2016.

37. Taşan-Kok, T. Entrepreneurial governance: Challenges of large-scale property-led urban regeneration projects. Tijdschr. Econ. Soc. Geogr. 2010, 101, 126-149. [CrossRef]

38. Atkinson, R.; Tallon, A.; Williams, D. Governing urban regeneration in the UK: A case of 'variegated neoliberalism' in action? Eur. Plan. Stud. 2019, 27, 1083-1106. [CrossRef]

39. Boisseuil, C. Governing ambiguity and implementing cross-sectoral programmes: Urban regeneration for social mix in Paris. J. Hous. Environ. Res. 2019, 34, 425-440. [CrossRef]

40. Price, N.J. How to Build a Strong Governance Model; Diligent Insights: New York, NY, USA, 2018.

41. Hendriks, F. Understanding Good Urban Governance: Essentials, Shifts, and Values. Urban Aff. Rev. 2014, 50, 553-576. [CrossRef]

42. Dijkstra, G. Aid and good governance: Examining aggregate unintended effects of aid. Eval. Program Plan. 2018, 68, 225-232. [CrossRef]

43. Kisingo, A.; Rollins, R.; Murray, G.; Dearden, P.; Clarke, M. Evaluating 'good governance': The development of a quantitative tool in the Greater Serengeti Ecosystem. J. Environ. Manag. 2016, 181, 749-755. [CrossRef]

44. Biddulph, M. Urban design, regeneration and the entrepreneurial city. Prog. Plan. 2011, 76, 63-103. [CrossRef]

45. Parés, M.; Martí-Costa, M.; Blanco, I. Geographies of governance: How place matters in urban regeneration policies. Urban Stud. 2014, 51, 3250-3267. [CrossRef]

46. Aalbers, M.B.; Van Beckhoven, E. The integrated approach in neighbourhood renewal: More than just a philosophy? Tijdschr. Econ. Soc. Geogr. 2010, 101, 449-461. [CrossRef]

47. Hemphill, L.; McGreal, S.; Berry, J.; Watson, S. Leadership, Power and Multisector Urban Regeneration Partnerships. Urban Stud. 2006, 43, 59-80. [CrossRef]

48. Gopakumar, G. Intrusiveness of urban renewal in India: JNNURM as a development fix. Can. J. Dev. Stud. 2014, 36, 89-106. [CrossRef]

49. Lefebvre, H. The Right to the City; Economica: Pairs, France, 1968. 
50. Pierre, J. Models of Urban Governance: The Institutional Dimension of Urban Politics. Urban Aff. Rev. 1999, 34, 372-396. [CrossRef]

51. Breda-Vázquez, I.; Conceição, P.; Fernandes, R. Partnership Diversity and Governance Culture: Evidence from Urban Regeneration Policies in Portugal. Urban Stud. 2009, 46, 2213-2238. [CrossRef]

52. Berkel, R.V. The decentralisation of social assistance in The Netherlands. Int. J. Sociol. Soc. Policy 2006, 26, 20-31. [CrossRef]

53. Lawless, P. Can area-based regeneration programmes ever work? Evidence from England's New Deal for Communities Programme. Policy Stud. 2012, 33, 313-328. [CrossRef]

54. Jing, Y.; Besharov, D.J. Collaboration among government, market, and society: Forging partnerships and encouraging competition. J. Policy Anal. Manag. 2014, 33, 835-842. [CrossRef]

55. Li, L.H. Urban renewal partnerships-Is there really room for participation from individual owners? A case study of Hong Kong. J. Hous. Built Environ. 2012, 27, 517-526. [CrossRef]

56. Ball, M.; Maginn, P.J. Urban change and conflict: Evaluating the role of partnerships in urban regeneration in the UK. Hous. Stud. 2005, 20, 9-28. [CrossRef]

57. Jonas, A.E.G.; McCarthy, L. Urban Management and Regeneration in the United States: State Intervention or Redevelopment at All Costs? Local Gov. Stud. 2009, 35, 299-314. [CrossRef]

58. Farhat, R. Accountability in urban regeneration partnerships: A role for design centers. Cities 2018, 72, 8-16. [CrossRef]

59. Bruce, A.; Clarson, D. Assessing the potential and limits of community-based initiatives in urban regeneration: Three decades of experience on Sheffield's Manor estate. Reg. Stud. Reg. Sci. 2017, 4, 80-93. [CrossRef]

60. Zhong, X.; Leung, H.H. Exploring Participatory Microregeneration as Sustainable Renewal of Built Heritage Community: Two Case Studies in Shanghai. Sustainability 2019, 11, 1617. [CrossRef]

61. Amirtahmasebi, R.; Orloff, M.; Wahba, S.; Altman, A. Regenerating Urban Land: A Practitioner's Guide to Leveraging Private Investment. In Urban Development; World Bank: Washington, DC, USA, 2016; Available online: https://openknowledge. worldbank.org/handle/10986/24377 (accessed on 18 December 2020).

62. Huston, S.; Rahimzad, R.; Parsa, A. 'Smart' sustainable urban regeneration: Institutions, quality and financial innovation. Cities 2015, 48, 66-75. [CrossRef]

63. Newman, P.; Davies-Slate, S.; Jones, E. The Entrepreneur Rail Model: Funding urban rail through majority private investment in urban regeneration. Res. Transp. Econ. 2018, 67, 19-28. [CrossRef]

64. Lawson, L.; Kearns, A. Community engagement in regeneration: Are we getting the point? J. Hous. Built Environ. 2009, 25, 19-36. [CrossRef]

65. Muir, J.; Rhodes, M.L. Vision and reality: Community involvement in Irish urban regeneration. Policy Politics 2008, 36, 497-520. [CrossRef]

66. Van Bortel, G.; Mullins, D.; Rhodes, M.L. Exploring network governance in urban regeneration, community involvement and integration. J. Hous. Built Environ. 2009, 24, 93-101. [CrossRef]

67. Ward, K.G. Coalitions in urban regeneration: A regime approach. Environ. Plan. A Econ. Space 1997, 29, 1493-1506. [CrossRef]

68. Kuyucu, T.; Ünsal, Ö. ‘Urban Transformation' as State-led Property Transfer: An Analysis of Two Cases of Urban Renewal in Istanbul. Urban Stud. 2010, 47, 1479-1499. [CrossRef]

69. Hyra, D.S. Conceptualizing the New Urban Renewal. Urban Aff. Rev. 2012, 48, 498-527. [CrossRef]

70. Sagan, I.; Grabkowska, M. Urban Regeneration in Gdańsk, Poland: Local Regimes and Tensions Between Top-Down Strategies and Endogenous Renewal. Eur. Plan. Stud. 2012, 20, 1135-1154. [CrossRef]

71. Raco, M. Governance, Urban. In International Encyclopedia of Human Geography; Elsevier: Amsterdam, The Netherlands, 2009; pp. 622-627.

72. Uršič, M.; Križnik, B. Comparing urban renewal in Barcelona and Seoul-Urban management in conditions of competition among global cities. Asia Eur. J. 2012, 10, 21-39. [CrossRef]

73. Fuller, C. 'Worlds of Justification' in the Politics and Practices of Urban Regeneration. Environ. Plan. D Soc. Space 2012, 30, 913-929. [CrossRef]

74. Clemente, M.; Salvati, L. 'Interrupted' Landscapes: Post-Earthquake Reconstruction in between Urban Renewal and Social Identity of Local Communities. Sustainability 2017, 9, 2015. [CrossRef]

75. Feldman, M. Urban Waterfront Regeneration and Local Governance in Tallinn. Eur. Asia Stud. 2000, 52, 829-850. [CrossRef]

76. Bernt, M. Partnerships for Demolition: The Governance of Urban Renewal in East Germany's Shrinking Cities. Int. J. Urban Reg. Res. 2009, 33, 754-769. [CrossRef]

77. Vento, A.T. Mega-project meltdown: Post-politics, neoliberal urban regeneration and Valencia's fiscal crisis. Urban Stud. 2017, 54, 68-84. [CrossRef]

78. Ng, M.K. Property-led urban renewal in Hong Kong: Any place for the community? Sustain. Dev. 2002, 10, 140-146. [CrossRef]

79. Kort, M.; Klijn, E.-H. Public-Private Partnerships in Urban Regeneration Projects: Organizational Form or Managerial Capacity? Public Adm. Rev. 2011, 71, 618-626. [CrossRef]

80. PPPLRC. Joint Ventures/Government Shareholding in Project Company. 2016. Available online: https://ppp.worldbank.org/ public-private-partnership/agreements/joint-ventures-empresas-mixtas (accessed on 29 November 2020).

81. Teernstra, A.B.; Pinkster, F.M. Participation in neighbourhood regeneration: Achievements of residents in a Dutch disadvantaged neighbourhood. Urban Res. Pract. 2015, 9, 56-79. [CrossRef] 
82. Kim, K. Rethinking Temporary Use Coordinators for the Regeneration of Underused Urban Spaces in Seoul. J. Reg. City Plan. 2019, 30, 1-12. [CrossRef]

83. Dargan, L. Participation and Local Urban Regeneration: The Case of the New Deal for Communities (NDC) in the UK. Reg. Stud. 2009, 43, 305-317. [CrossRef]

84. De Medici, S.; Riganti, P.; Viola, S. Circular Economy and the Role of Universities in Urban Regeneration: The Case of Ortigia, Syracuse. Sustainability 2018, 10, 4305. [CrossRef]

85. Van der Pennen, T.; Van Bortel, G. Exemplary Urban Practitioners in Neighbourhood Renewal: Survival of the Fittest ... and the Fitting. VOLUNTAS: Int. J. Volunt. Nonprofit Organ. 2015, 27, 1323-1342. [CrossRef]

86. Mullins, D.; Bortel, G.V. Neighbourhood regeneration and place leadership lessons from Groningen and Birmingham. Policy Stud. 2010, 31, 413-428. [CrossRef]

87. Savini, F. The Endowment of Community Participation: Institutional Settings in Two Urban Regeneration Projects. Int. J. Urban Reg. Res. 2010, 35, 949-968. [CrossRef]

88. Jones, P.S. Urban Regeneration's Poisoned Chalice: Is There an Impasse in (Community) Participation-based Policy? Urban Stud. 2003, 40, 581-601. [CrossRef]

89. Evans, J.; Jones, P. Rethinking Sustainable Urban Regeneration: Ambiguity, Creativity, and the Shared Territory. Environ. Plan. A Econ. Space 2009, 40, 1416-1434. [CrossRef]

90. Kleinhans, R. False promises of co-production in neighbourhood regeneration: The case of Dutch community enterprises. Public Manag. Rev. 2017, 19, 1500-1518. [CrossRef]

91. Dicks, B. Participatory Community Regeneration: A Discussion of Risks, Accountability and Crisis in Devolved Wales. Urban Stud. 2013, 51, 959-977. [CrossRef]

92. Garcia, M.Á.H.; Rodríguez, R.M.; Moreno, R.M. Urban Regeneration Policy from the Integrated Urban Development Model in the European Union: An Analytical Approach Based on the Study of Spanish Cities. Local Gov. Stud. 2015, 42, 267-286. [CrossRef]

93. Parés, M.; Bonet-Martí, J.; Martí-Costa, M. Does Participation Really Matter in Urban Regeneration Policies? Exploring Governance Networks in Catalonia (Spain). Urban Aff. Rev. 2011, 48, 238-271. [CrossRef]

94. Degen, M.; Garcia, M. The Transformation of the 'Barcelona Model': An Analysis of Culture, Urban Regeneration and Governance. Int. J. Urban Reg. Res. 2012, 36, 1022-1038. [CrossRef]

95. Bull, A.C.; Jones, B. Governance and Social Capital in Urban Regeneration: A Comparison between Bristol and Naples. Urban Stud. 2006, 43, 767-786. [CrossRef]

96. Lidegaard, C.; Nuccio, M.; Bille, T. Fostering and planning urban regeneration: The governance of cultural districts in Copenhagen. Eur. Plan. Stud. 2017, 26, 1-19. [CrossRef]

97. Bacqué, M.-H.; Biewener, C. Different Manifestations of the Concept of Empowerment: The Politics of Urban Renewal in the United States and the United Kingdom. Int. J. Urban Reg. Res. 2013, 37, 2198-2213. [CrossRef]

98. Beauregard, R.A. Public-Private Partnerships as Historical Chameleons: The Case of the United States. In Partnerships in Urban Governance; Palgrave Macmillan: London, UK, 1998; pp. 52-70.

99. Dempsey, N.; Bramley, G.; Power, S.; Brown, C. The social dimension of sustainable development: Defining urban social sustainability. Sustain. Dev. 2011, 19, 289-300. [CrossRef]

100. Evans, B. Governing for Sustainable Urban Development. J. Environ. Policy Plan. 2011, 13, 73-74. [CrossRef]

101. Zhou, Z. Towards collaborative approach? Investigating the regeneration of urban village in Guangzhou, China. Habitat Int. 2014 44, 297-305. [CrossRef]

102. Liebmann, H.; Kuder, T. Pathways and Strategies of Urban Regeneration-Deindustrialized Cities in Eastern Germany. Eur. Plan. Stud. 2012, 20, 1155-1172. [CrossRef]

103. Wallace, A. New Neighbourhoods, New Citizens? Challenging 'Community' as a Framework for Social and Moral Regeneration under New Labour in the UK. Int. J. Urban Reg. Res. 2010, 34, 805-819. [CrossRef]

104. Whitehead, M. 'In the shadow of hierarchy': Meta-governance, policy reform and urban regeneration in the West Midlands. Area 2002, 35, 6-14. [CrossRef]

105. Seo, B.K.; Joo, Y.-M. Innovation or episodes? Multi-scalar analysis of governance change in urban regeneration policy in South Korea. Cities 2019, 92, 27-35. [CrossRef]

106. Cocks, M. Conceptualizing the Role of Key Individuals in Urban Governance: Cases from the Economic Regeneration of Liverpool, UK. Eur. Plan. Stud. 2013, 21, 575-595. [CrossRef]

107. Keresztély, K.; Scott, J.W. Urban Regeneration in the Post-Socialist Context: Budapest and the Search for a Social Dimension. Eur. Plan. Stud. 2012, 20, 1111-1134. [CrossRef]

108. Ruming, K.; Tice, A.; Freestone, R. Commonwealth Urban Policy in Australia: The case of inner urban regeneration in Sydney, 1973-75. Aust. Geogr. 2010, 41, 447-467. [CrossRef]

109. Beatty, C.; Foden, M.; Lawless, P.; Wilson, I.; Christina, B.; Mike, F.; Paul, L.; Ian, W. Area-based regeneration partnerships and the role of central government: The New Deal for Communities programme in England. Policy Politics 2010, 38, 235-251. [CrossRef]

110. Van Bortel, G.; Mullins, D. Critical perspectives on network governance in urban regeneration, community involvement and integration. J. Hous. Built Environ. 2009, 24, 203-219. [CrossRef]

111. Lin, C.-Y.; Hsing, W.-C. Culture-led Urban Regeneration and Community Mobilisation: The Case of the Taipei Bao-an Temple Area, Taiwan. Urban Stud. 2009, 46, 1317-1342. [CrossRef] 
112. Haffner, M.; Elsinga, M. Deadlocks and breakthroughs in urban renewal: A network analysis in Amsterdam. J. Hous. Built Environ. 2009, 24, 147-165. [CrossRef]

113. Osei, P. Managing Urban Regeneration in Jamaica: The Cluster Implementation Approach and Outcomes. Local Gov. Stud. 2009, 35, 315-334. [CrossRef]

114. North, D.; Syrett, S. Making the Links: Economic Deprivation, Neighbourhood Renewal and Scales of Governance. Reg. Stud. 2008, 42, 133-148. [CrossRef]

115. Orueta, F.D. Madrid: Urban regeneration projects and social mobilization. Cities 2007, 24, 183-193. [CrossRef]

116. Card, P.; Mudd, J. The Role of Housing Stock Transfer Organisations in Neighbourhood Regeneration: Exploring the Relationship between Regeneration, 'New Localism' and Social Networks. Hous. Stud. 2007, 21, 253-267. [CrossRef]

117. Hull, A. Facilitating Structures for Neighbourhood Regeneration in the UK: The Contribution of the Housing Action Trusts. Urban Stud. 2006, 43, 2317-2350. [CrossRef]

118. Johnson, C.; Osborne, S.P. Local Strategic Partnerships, Neighbourhood Renewal, and the Limits to Co-governance. Public Money Manag. 2003, 23, 147-154. [CrossRef]

119. McGuirk, P.M. Power and policy networks in urban governance: Local government and property-led regeneration in Dublin. Urban Stud. 2000, 37, 651-672. [CrossRef]

120. Raco, M. Business Associations and the Politics of Urban Renewal: The Case of the Lower Don Valley, Sheffield. Urban Stud. 1997, 34, 383-402. [CrossRef]

121. Imrie, R.; Thomas, H.; Marshall, T. Business Organizations, Local Dependence and the Politics of Urban-Renewal in Britain. Urban Stud. 1995, 32, 31-47. [CrossRef] 